\title{
Advanced
}
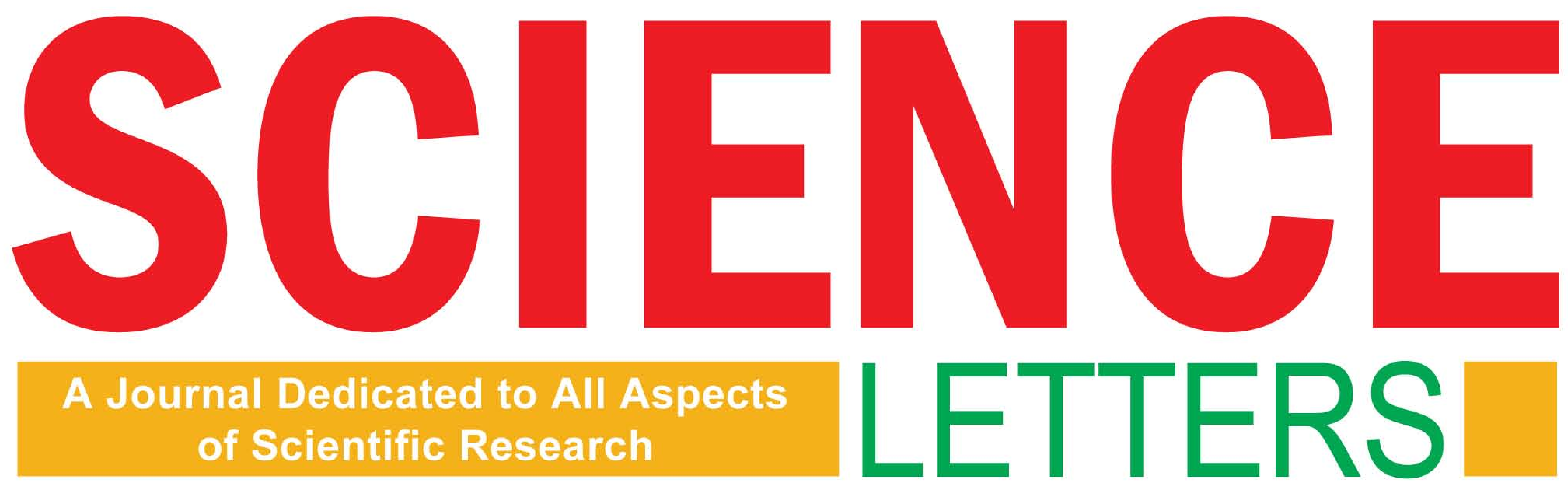

Editor-in-Chief: Dr. Hari Singh Nalwa, USA

\section{Special Issue on}

International Conference on Information in Business and Technology Management (I2BM'17)

Penang, Malaysia, 18-20 April, 2017

GUEST EDITORS: Hamzah Asyrani Sulaiman, Mohd Azlishah Othman,

Ahmad Na'im Che Pee@Che Hanapi, Mohd Fairuz Iskandar Othman, and Yahaya Abd Rahim 2016 International Conference on Computational Science and Engineering (ICCSE2016)

Kota Kinabalu, Sabah, Malaysia, 29-30 November, 2016

GUEST EDITORS: Rayner Alfred and Chin Kim On

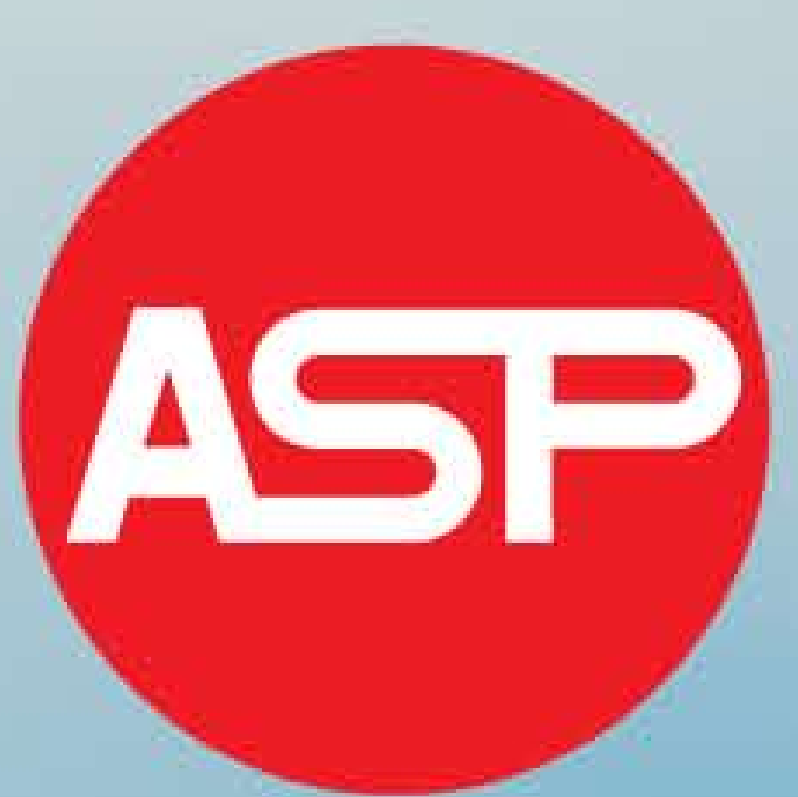

AMERICAN SCIENTIFIC PUBLISHERS 


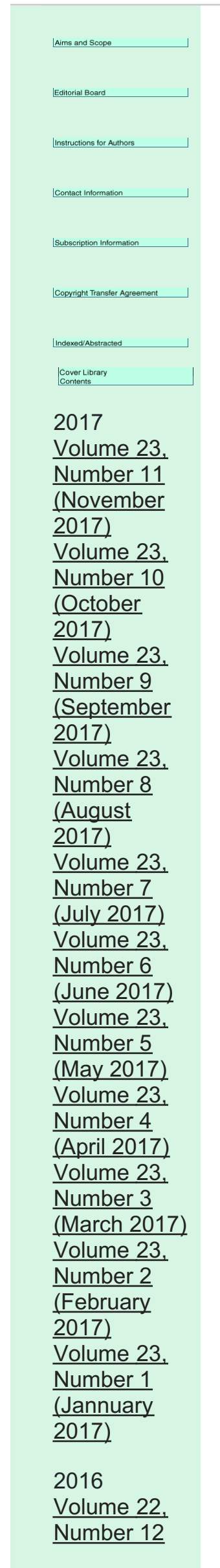

Advanced Science Letters

ISSN: 1936-6612 (Print): EISSN: 1936-7317 (Online)

Copyright () 2000-2017 American Scientific Publishers. All

Rights Reserved.

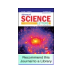

ADVANCED SCIENCE LETTERS is a multidisciplinary peer-reviewed journal with a very wide-ranging coverage, consolidates fundamental and applied research activities by publishing proceedings from international scientific, technical and medical conferences in all areas of (1) Physical Sciences, (2) Engineering, (3) Biological Sciences/Health Sciences,

(4) Medicine, (5) Computer and Information Sciences,

(6) Mathematical Sciences, (7) Agriculture Science and

Engineering, (8) Geosciences, and (9)

Energy/Fuels/Environmental/Green Science and

Engineering, and (10) Education, Social Sciences and Public Policies. This journal does not publish general research articles by individual authors.

Editor-in-Chief: Dr. Hari Singh Nalwa, USA

\section{Contact for Conference Proceedings:}

For publishing Conference proceedings, contact Editorin-Chief: Dr. Hari Singh Nalwa

Vo

A SPECIAL SECTION

Selected Peer-Reviewed Articles from the International Conference on Information in Business and Technology Management (I2BM'17), Penang, Malaysia, 18-20 April, 2017 Guest Editors: Hamzah Asyrani Sulaiman, Mohd Azlishah Othman, Ahmad Na'im Che Pee@Che Hanapi,

Mohd Fairuz Iskandar Othman, and Yahaya Abd Rahim

Adv. Sci. Lett. 23, 10481-10482 (2017)

[Abstract] [Full Text - PDF] [Purchase Article]

\section{RESEARCH ARTICLES}

The Implementation of Koha and RFID Self Service

Framework in Education Resource Centre

Amzari Abu Bakar, Mohd Ridhwan Kamaruzaman, Mazwani Ayu

Mazlan, Mohd Razilan Abdul Kadir,

Fadhilnor Rahmad, and Mohd Yusof Mustaffar

Adv. Sci. Lett. 23, 10483-10487 (2017)

[Abstract] [Full Text - PDF] [Purchase Article]

\section{A Preliminary Study on Social Media Use in Government Agencies \\ Maslinda Mohd Nadzir, Nafishah Othman, and Siti Sakira Kamaruddin \\ Adv. Sci. Lett. 23, 10488-10491 (2017) \\ [Abstract] [Full Text - PDF] [Purchase Article]}

3R-IG: An Edutainment Approach to Reduce, Reuse and Recycle

Han-Foon Neo, Chuan-Chin Teo, and Jun Xiong Goh

Adv. Sci. Lett. 23, 10492-10496 (2017)

[Abstract] [Full Text - PDF] [Purchase Article]

A Review of Business Failure Prediction Models Used on

\section{Encyclopedia of \\ Nanoscience and \\ Nanotechnolgy \\ 25-Volumes Set}

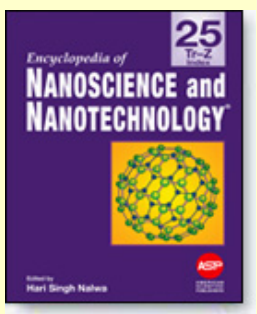

CALL FOR PAPERS
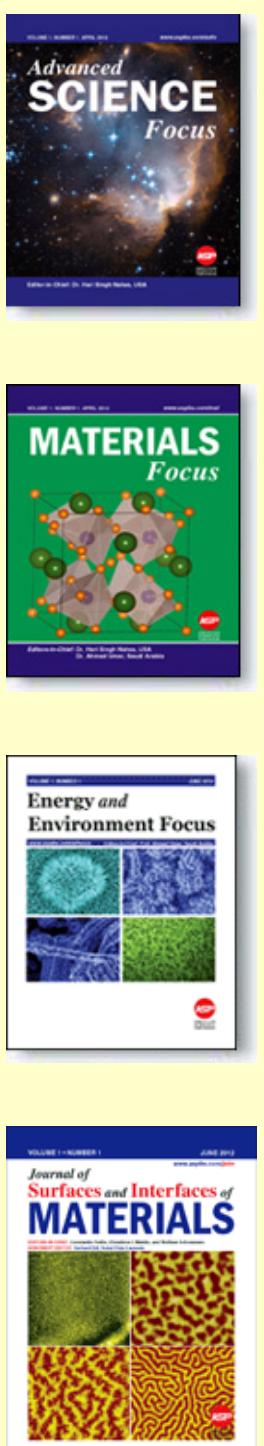
(December 2016)

Volume 22,

Number 11

(November

2016)

Volume 22,

Number 10

October

2016)

Volume 22,

Number 9

(September

2016)

Volume 22,

Number 8

(August

2016)

Volume 22,

Number 7

(July 2016)

Volume 22,

Number 4

(April 2016)

Volume 22,

Number 3

(March 2016)

Volume 22,

Number 2

(February

2016)

Volume 22,

Number 1

(January

2016)

2015

Volume 21.

Number 12

(December

2015)

Volume 21,

Number 11

(November

2015)

Volume 21.

Number 10

(October

2015)

Volume 21.

Number 9

September

2015)

Volume 21.

Number 8

(August

2015)

Volume 21.

Number 7

(July 2015)

Volume 21.

Number 6

(June 2015)

Volume 21,

Number 5
Financial Distressed Companies

Nur Diyana Abdullah and Sulaiman Abdul Malik

Adv. Sci. Lett. 23, 10497-10502 (2017)

[Abstract] [Full Text - PDF] [Purchase Article]

Understanding Leisure Travelling Motivation Among

Malaysian with Mobility Impairment

Noor Syahieda Mat Shah, Nur Farhana Mohd Sah, Norol Hamiza

Zamzuri, Inoormaziah Azman, and Norzaidi Mohd Daud

Adv. Sci. Lett. 23, 10503-10505 (2017)

[Abstract] [Full Text - PDF] [Purchase Article]

Criminological and Psychological Analysis of Failure to Fulfill Responsibilities for the Upbringing of a Minor

Yana Korneeva and Nina Skripchenko

Adv. Sci. Lett. 23, 10506-10510 (2017)

[Abstract] [Full Text - PDF] [Purchase Article]

Psychological Safety of Oil and Gas Workers in the

Conditions of Group Isolation of the Arctic

Yana Korneeva and Natalia Simonova

Adv. Sci. Lett. 23, 10511-10514 (2017)

[Abstract] [Full Text - PDF] [Purchase Article]

Intention to Purchase Medical and Health Insurance:

Application of Theory of Planned Behavior

Mohd Redhuan Dzulkipli, Nik Nursyazwani Nik Zainuddin, Siti

Noorsuriani Maon, Aziz Jamal, and Muhamad Khalil Omar

Adv. Sci. Lett. 23, 10515-10518 (2017)

[Abstract] [Full Text - PDF] [Purchase Article]

Engaging the Echo Boomer: Teamwork at Workplace

Zarina Abdul Munir, Shamsul Azren Mohd Shukor, Veera

Pandiyan Kaliani Sundram, Mohd Redhuan Dzulkipli,

and Norahimah Shaharudin

Adv. Sci. Lett. 23, 10519-10523 (2017)

[Abstract] [Full Text - PDF] [Purchase Article]

Modification of Economic Psychological Model in Profiling

Graduates for Entrepreneurial Intentions

NurFarhanaMohd Sah, Noor SyahiedaMat Shah, NorolHamiza

Zamzuri, and AyuRohaidah Ghazali

Adv. Sci. Lett. 23, 10524-10527 (2017)

[Abstract] [Full Text - PDF] [Purchase Article]

The Impact of Database Structure on Join Query's Energy

Consumption

Rohiza Ahmad, Aliza Sarlan, and Shuib Basri

Adv. Sci. Lett. 23, 10528-10532 (2017)

[Abstract] [Full Text - PDF] [Purchase Article]

Colombian Tourism: Proposal App to Foster Smart Tourism in the Country

Marvin Alexis Cubides Ruíz, Sindy Tatiana Bohorquez, and José Ignacio Rodríguez Molano

Adv. Sci. Lett. 23, 10533-10537 (2017)

[Abstract] [Full Text - PDF] [Purchase Article]

The Antecedents Buying Intention of New Smartphone Among University Students

Azira Rahim, Law Kuan Kheng, Kamarul Ariffin Mansor, and

Nurliyana Abas

Adv. Sci. Lett. 23, 10538-10541 (2017)

[Abstract] [Full Text - PDF] [Purchase Article]

The Role of Emotional Investment and Social Influence in

Predicting Individual Self-Esteem for Social

Media User Among Youth

Norol Hamiza Zamzuri

Adv. Sci. Lett. 23, 10542-10543 (2017)

[Abstract] [Full Text - PDF] [Purchase Article]

Incorporating Islamic Values into Business Towards Holistic

Shariah Compliance

Siti Anisah Atan, Norjariah Arif, and Kamilah Ahmad
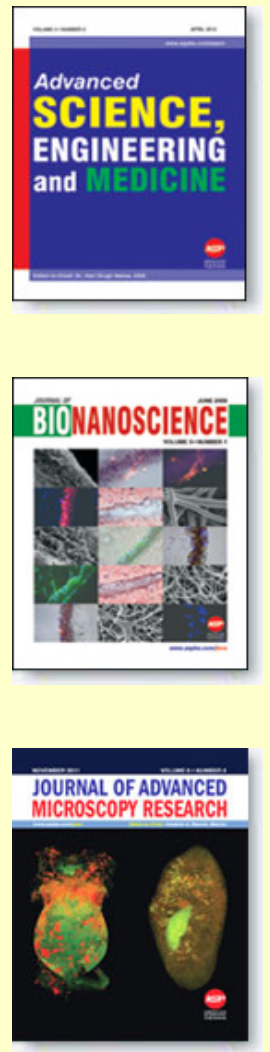
(May 2015)

Volume 21.

Number 4

(April 2015)

Volume 21.

Number 3

(March 2015)

Volume 21,

Number 2

(February

2015)

Volume 21,

Number 1

(January

2015)

2014

Volume 20,

Number

10/11/12

(Oct/Nov/Dec

2014)

Volume 20 ,

Number 7/8/9

(Jul/Aug/Sep

2014)

Volume 20 ,

Number 5/6

(May/Jun

2014)

Volume 20.

Number 3/4

(Mar/Apr

2014)

Volume 20,

Number 2

February

2014)

Volume 20,

Number 1

(January

2014)

2013

Volume 19.

Number 12

(December

2013)

Volume 19.

Number 11

(November

2013)

Volume 19.

Number 10

(October

2013)

Volume 19,

Number 9

(September

2013)

Volume 19.

Number 8

(August

2013)

Volume 19,
Adv. Sci. Lett. 23, 10544-10548 (2017)

[Abstract] [Full Text - PDF] [Purchase Article]

Transaction Cost Analysis in New Product Development Process

Sasivimol Meeampol and Anyanitha Distanont

Adv. Sci. Lett. 23, 10549-10554 (2017)

[Abstract] [Full Text - PDF] [Purchase Article]

An Investigation into Students' Misconception on Electrolyte and Non-Electrolytes Solutions with Two Tier

Diagnostic Test Based Pictorial

Nahadi, Wiwi Siswaningsih, and Hanifah Kurnia Muchtar

Adv. Sci. Lett. 23, 10555-10558 (2017)

[Abstract] [Full Text - PDF] [Purchase Article]

The Curvilinear Relationship Between Customer and Market

Penetration Capability Familiarity Character

Suherna

Adv. Sci. Lett. 23, 10559-10562 (2017)

[Abstract] [Full Text - PDF] [Purchase Article]

Multi-Informational Auto Tracking Algorithm

Davood Pour Yousefian Barfeh, Neil Balba, Ricky Bustamante,

Eliezer Albacea, Editha Jose, and Vladimir Mariano

Adv. Sci. Lett. 23, 10563-10567 (2017)

[Abstract] [Full Text - PDF] [Purchase Article]

The Determinants of Online Information Sharing Behavior Among Millennials in Malaysia

Ahmad lqbal Hakim Suhaimi, Hazirah Afifah Abd Rahim, Fauziah

Redzuan, Wan Abdul Rahim Wan Isa,

and Wan Adilah Wan Adnan

Adv. Sci. Lett. 23, 10568-10572 (2017)

[Abstract] [Full Text - PDF] [Purchase Article]

Mobile Applications: Integrated User Acceptance Model Niken F. Ernungtyas, Billy Sarwono, Eriyanto Eriyanto, and Irwansyah Irwansyah

Adv. Sci. Lett. 23, 10573-10576 (2017)

[Abstract] [Full Text - PDF] [Purchase Article]

Academic Cheating and Fraud Triangle Theory:

Undergraduate Students' Perspectives

Nurhaiyyu Abdull Hamid, Mohamad Ridhuan Mat Dangi,

Nurshamimi Sabli, Mohd Fairuz Adnan, and Roslan Abdul Wahab

Adv. Sci. Lett. 23, 10577-10581 (2017)

[Abstract] [Full Text - PDF] [Purchase Article]

Online Health Information Seeking Behavior Pattern

Siti Noorsuriani Maon, Naffisah Mohd Hassan, and Sharidatul

Akma Abu Seman

Adv. Sci. Lett. 23, 10582-10585 (2017)

[Abstract] [Full Text - PDF] [Purchase Article]

An Evaluation of Religion Based Co-Operatives Performance Dimension

Abdullah Sallehhudin, Al Mansor Abu Said, Nor Hasmanto Abu Hasan, Mohd Ariff Mustafa, Md Shukor Masuod,

Azizi Samsudin, Mohammad Jais, and Hishamuddin Ismail

Adv. Sci. Lett. 23, 10586-10590 (2017)

[Abstract] [Full Text - PDF] [Purchase Article]

Sawdust Ceramic Firing: An Alternative Technique in Natural Clay Body Colouring

Syed Zamzur Akasah Syed Ahmed Jalaluddin, Mohamad Rizal

Salleh, Mohd Suhaimi Tohid, and

Muhamad Khairi Shamsudin

Adv. Sci. Lett. 23, 10591-10594 (2017)

[Abstract] [Full Text - PDF] [Purchase Article]

Business Process and Business System Required Along

SMEs Growth (Case Study in Fashion Industry)

Made Andriani and Joko Siswanto 
Number 7

(July 2013)

Volume 19,

Number 6

(June 2013)

Volume 19,

Number 5

(May 2013)

Volume 19,

Number 4

(April 2013)

Volume 19,

Number 3

(March 2013)

Volume 19,

Number 2

(February

2013)

Volume 19,

Number 1

(January

2013)

2012

Volume 18

(Nov/Dec

2012)

Volume 17

October

2012)

Volume 16

September

2012)

Volume 15

(August

2012)

Volume 14

(July 2012)

Volume 13

(30 June

2012)

Volume 12

(15 June

2012)

Volume 11

(30 May

2012)

Volume 10

(15 May

2012)

Volume 9 (30

April 2012)

Volume 8(15

April 2012)

Volume 7 (30

March 2012)

Volume 6 (15

March 2012)

Volume 5

Number 2

(February

2012)

Volume 5 ,
Adv. Sci. Lett. 23, 10595-10600 (2017)

[Abstract] [Full Text - PDF] [Purchase Article]

Enhancing Social Enterprise with Innovation Systems

Bordin Rassamethes and Orapan Khongmalai

Adv. Sci. Lett. 23, 10601-10605 (2017)

[Abstract] [Full Text - PDF] [Purchase Article]

Balancing Acquisition and Retention Accommodating Capacity Expansion in a Telecommunication Company Indah Victoria Sandroto, Budhi Prihartono, Rajesri Govindaraju, and Kadarsah Suryadi

Adv. Sci. Lett. 23, 10606-10611 (2017)

[Abstract] [Full Text - PDF] [Purchase Article]

Review on Wall Art Around Shah Alam, Selangor, Malaysia

Farid Raihan Ahmad, Syed Zamzur Akasah Syed Ahmed

Jalaluddin, and Muhammad Khairi Shamsudin

Adv. Sci. Lett. 23, 10612-10615 (2017)

[Abstract] [Full Text - PDF] [Purchase Article]

Issues Related to Low Commercialisation Rates of the

University's Research and Development (R\&D)

Products: Industrial Perspective

R. Ali, A. M. Leman, N. M. Sunar, and A. N. Ahmad

Adv. Sci. Lett. 23, 10616-10620 (2017)

[Abstract] [Full Text - PDF] [Purchase Article]

Factor That Impacts the Capability Development and

Sustainable Income of the Rural Development

Programme in Malaysia

Amir Imran Zainoddin, Azlan Amran, and Mohd Rizaimy

Shaharudin

Adv. Sci. Lett. 23, 10621-10624 (2017)

[Abstract] [Full Text - PDF] [Purchase Article]

Analysis of Students' Mathematics Performance in Solving the PISA Standard Based Test Item Using a

Qualitative Content Analysis Method

Sunardi and Dian Kurniati

Adv. Sci. Lett. 23, 10625-10628 (2017)

[Abstract] [Full Text - PDF] [Purchase Article]

Designing Batik with an Alternative Batik Techniques Using

Wax Application

Mohd Azhar Samin, Nor Azrin Ramli, and Rafeah Legino

Adv. Sci. Lett. 23, 10629-10631 (2017)

[Abstract] [Full Text - PDF] [Purchase Article]

The Operational Efficiency Analysis of Insurance Companies in Thailand

Anupong Wongchai

Adv. Sci. Lett. 23, 10632-10635 (2017)

[Abstract] [Full Text - PDF] [Purchase Article]

Social Media Based Proposed Model for Museum Marketing Strategy in Yogyakarta

Ayu Helena Cornellia, Heddy Shri Ahimsa Putra, Tri Kuntoro

Priyambodo, and Yulia Arisnani Widyaningsih

Adv. Sci. Lett. 23, 10636-10639 (2017)

[Abstract] [Full Text - PDF] [Purchase Article]

Hypotheses of Relationships Between Elements in Movie Trailers with Purchase Intention of Movie Tickets

Mohd Syuhaidi Abu Bakar, Raja Nor Aminah Raja Ayob, and

Hafizah Rosli

Adv. Sci. Lett. 23, 10640-10642 (2017)

[Abstract] [Full Text - PDF] [Purchase Article]

Malaysian NPOs' Reporting: Where Do They Stand?

Nur Farahah Mohd Pauzi, Roshayani Arshad, Nurfarahin Roslan, and Noreena Md Yusoff

Adv. Sci. Lett. 23, 10643-10647 (2017)

[Abstract] [Full Text - PDF] [Purchase Article] 
Number 1

(January

2012)

2011 ,

Volume 4

Volume 4.

Number

11/12 (Nov/

Dec 2011)

Volume 4.

Number

8/9/10 (Aug

/Sep/Oct

2011)

Volume 4.

Number $6 / 7$

(June / July

2011)

Volume 4.

Number 4/5

(April / May

2011)

Volume 4,

Number 3

(March 2011)

Volume 4.

Number 2

(February

2011)

Volume 4.

Number 1

(January

2011)

2010 ,

Volume 3

Volume 3.

Number 4

(December

2010)

Volume 3 ,

Number 3

(September

2010)

Volume 3 ,

Number 2

(June 2010)

Volume 3 ,

Number 1

(March 2010)

2009 ,

Volume 2

Volume 2,

Number 4

(December

2009)

Volume 2,

Number 3

(September

2009)

Volume 2,

Number 2

(June 2009)
The Impact of XRace Game Board as an Experiential Learning Approach

Rosemawati Ali, Nur Izzah Jamil, Siti Noor Dina Ahmad, Nadiah

Mohamed, and Nurul Aityqah Yaacob

Adv. Sci. Lett. 23, 10648-10651 (2017)

[Abstract] [Full Text - PDF] [Purchase Article]

Supply Chain Management Components and Firm

Performance: Evidence from Thailand

Veera Boonjing, Pisit Chanvarasuth, and Chalermsak

Lertwongsatien

Adv. Sci. Lett. 23, 10652-10655 (2017)

[Abstract] [Full Text - PDF] [Purchase Article]

Enforcement of Safety and Health Policy Reduces Human Error in SMEs in the Manufacturing Industry

Jian Ai Yeow, Mohamad Khan Bin Jamal Khan, and Poh Kiat Ng

Adv. Sci. Lett. 23, 10656-10659 (2017)

[Abstract] [Full Text - PDF] [Purchase Article]

Safety Performance in the Workplace: A Proposed Model for Understanding the Influencing Factors on

Safety Climate

Yusliza Mohd Yusoff, Shaizatulaqma Kamalul Ariffin, Khatijah

Omar, and Sergio Manuel Madero-Gomez

Adv. Sci. Lett. 23, 10660-10663 (2017))

[Abstract] [Full Text - PDF] [Purchase Article]

Reduce Semantic Gap in Content-Based Image Retrieval

Jasman Pardede and Benhard Sitohang

Adv. Sci. Lett. 23, 10664-10671 (2017)

[Abstract] [Full Text - PDF] [Purchase Article]

Confidence in Halal Logo Strengthens the Relationship Between Consumer's Value-Expressive Function and

Attitude Toward Kopitiam (Coffee Shop)

Shaizatulaqma Kamalul Ariffin and Nabsiah Abdul Wahid

Adv. Sci. Lett. 23, 10672-10675 (2017)

[Abstract] [Full Text - PDF] [Purchase Article]

Interface Design Principles Appraisal for Teaching Aids in Tertiary Level

Norfadilah Kamaruddin and Shahrunizam Sulaiman

Adv. Sci. Lett. 23, 10676-10679 (2017)

[Abstract] [Full Text - PDF] [Purchase Article]

Employees' Understanding of HRM Practices in the Hotel Industry

Nik Hazimah Nik Mat, Yusnita Yusof, Hayatul Safrah Salleh, and Wan Norhayati Mohamed

Adv. Sci. Lett. 23, 10680-10683 (2017)

[Abstract] [Full Text - PDF] [Purchase Article]

Melayu Economic Harmonization Policy: A Social-Economic Approach

Bayu Taufiq Possumah, Tati Salmiaty, and Gunawan Baharuddin Adv. Sci. Lett. 23, 10684-10687 (2017)

[Abstract] [Full Text - PDF] [Purchase Article]

Family Ownership, Firm Performance and Capital Structure: Malaysian Evidence

Noor Hasniza Haron, Zuraidah Mohd Zam, and Nik Anis Idayu Nik Abdullah

Adv. Sci. Lett. 23, 10688-10691 (2017)

[Abstract] [Full Text - PDF] [Purchase Article]

The Impact of Information Systems on Financial Audit: An

Over View of External Auditors' Preparedness

to Tackle Clients Automated Environment

Asha Baleche Katamba, Angelina Yee Seow Voon, How Shi Min, and Hsin Vonn Seow

Adv. Sci. Lett. 23, 10692-10695 (2017)

[Abstract] [Full Text - PDF] [Purchase Article]

From Survey to Social Media: Public Opinion and Politics in 
Volume 2,

Number 1

(March 2009)

2008,

Volume 1

Volume 1,

Number 2

(December

2008)

Volume 1.

Number 1

(June 2008) the Age of Big Data

Shahnon Mohamed Salleh

Adv. Sci. Lett. 23, 10696-10700 (2017)

[Abstract] [Full Text - PDF] [Purchase Article]

Green Attitude Awareness Towards Performance of Quality Solid Waste Collection Services

Zikri Muhammad, Jaharudin Padli, Bayu Taufiq Possumah, Tarmiji Masron, and Jabil Mapjabil

Adv. Sci. Lett. 23, 10701-10704 (2017)

[Abstract] [Full Text - PDF] [Purchase Article]

Engaging Open Source Technology in Resources Center Using Koha ILMS: A Case Study at Sekolah Menengah

Petaling Jaya Selangor Malaysia

Mazwani Ayu binti Mazlan, Amzari bin Abu Bakar, Ahmad Nadzri

bin Mohamad, Ridwan bin Seman @ Kamarulzaman,

Mohamad Fazli bin Baharuddin, and Nurhidayah binti Hashim

Adv. Sci. Lett. 23, 10705-10708 (2017)

[Abstract] [Full Text - PDF] [Purchase Article]

The Integration of Engineering Calculations: ENGIEPRO

Aliza Sarlan, Wan Fatimah Wan Ahmad, Nurul Shamira Rashikin,

M. Zamri Abdullah, and Rohiza Ahmad

Adv. Sci. Lett. 23, 10709-10714 (2017)

[Abstract] [Full Text - PDF] [Purchase Article]

Development of Creative Economy Learning Model: Based ICT Subject in Entrepreneurship at Vocational High

School in West Java

Darma Rika Swaramarinda and Dewi Nurmalasari

Adv. Sci. Lett. 23, 10715-10720 (2017)

[Abstract] [Full Text - PDF] [Purchase Article]

Transparency and Accountability of Financial Management in Pesantren (Islamic Education Institution)

Yunika Murdayanti and Dita Puruwita

Adv. Sci. Lett. 23, 10721-10725 (2017)

[Abstract] [Full Text - PDF] [Purchase Article]

Malaysian Batik Sarong Layout Design

Rafeah Legino, Norizan Sajar, Norwani Md. Nawawi, Muhamad

Fairus Kamaruzaman, and Nazirah Mohamad Ba'ai

Adv. Sci. Lett. 23, 10726-10728 (2017)

[Abstract] [Full Text - PDF] [Purchase Article]

Traditional Flower Bath as an Inspiration into Creative Visual Artwork

Syazalia Roslan, Rafeah Legino, and Norizan Sajar

Adv. Sci. Lett. 23, 10729-10731 (2017)

[Abstract] [Full Text - PDF] [Purchase Article]

Establishing Policy for the Implementation of Electronic

Document and Records Management System in

Public Sector in Malaysia: The Influencing Factors

Azlina Ab Aziz, Zawiyah M. Yusof, Umi Asma' Mokhtar, and Dian Indrayani Jambari

Adv. Sci. Lett. 23, 10732-10736 (2017)

[Abstract] [Full Text - PDF] [Purchase Article]

Frontier Quantile Model Using a Generalized Class of Skewed Distributions

Varith Pipitpojanakarn, Woraphon Yamaka, Songsak

Sriboonchitta, and Paravee Maneejuk

Adv. Sci. Lett. 23, 10737-10742 (2017)

[Abstract] [Full Text - PDF] [Purchase Article]

Expectile and Quantile Kink Regressions with Unknown Threshold

Varith Pipitpojanakarn, Paravee Maneejuk, Woraphon Yamaka, and Songsak Sriboonchitta

Adv. Sci. Lett. 23, 10743-10747 (2017)

[Abstract] [Full Text - PDF] [Purchase Article] 
Examining the Perception of Attendees on Sustainable Efforts Towards Event Greening Using the Values,

Beliefs and Norms Theory

Nor Lela Ahmad, Nik Hasnaa Nik Mahmood, Wan Edura Wan

Rashid, Noor Azlina Mohamed Yunus,

Mohd Hanafi Azman Ong, and Ainin Sofia Muhamad Asri

Adv. Sci. Lett. 23, 10748-10752 (2017)

[Abstract] [Full Text - PDF] [Purchase Article]

Accounting Standards Perceptions in Small Medium

Enterpricess: Case Study in Indonesia

Nuramalia Hasanah and Z. R. RatnaAnggraini

Adv. Sci. Lett. 23, 10753-10756 (2017)

[Abstract] [Full Text - PDF] [Purchase Article]

Identification of Online Marketing Strategy to Success in the Survival Stage of Small Businesses

Aditya Parama Setiaboedi, Hasrini Sari, and Budhi Prihartono

Adv. Sci. Lett. 23, 10757-10760 (2017)

[Abstract] [Full Text - PDF] [Purchase Article]

The Effect of Perceived Corporate Social Responsibility Initiatives Towards Loyalty Intention Among Four and Five Star Hotels in Malaysia: The Mediating Effect of Brand Preference

Aslinda Mohd Shahril, Noor Amyra Ashaari, Rasidah Hamid,

Sabaianah Bachok, and Noradzhar Baba

Adv. Sci. Lett. 23, 10761-10764 (2017)

[Abstract] [Full Text - PDF] [Purchase Article]

Identifying Green Practice Measures Through Formative Construct

Mohd Raziff Jamaluddin, Hamizad Abdul Hadi, Salleh Mohd Radzi, and Mohamad Hemdi

Adv. Sci. Lett. 23, 10765-10768 (2017)

[Abstract] [Full Text - PDF] [Purchase Article]

Sustainability of the Batik Block Industry in Kelantan and Terengganu

Rabiatuadawiyah Kari, Mohd Azhar Samin, and Rafeah Legino Adv. Sci. Lett. 23, 10769-10773 (2017)

[Abstract] [Full Text - PDF] [Purchase Article]

Empowering Self Potential in the Enhancement of Business Management for People with Disabilities in Bandung

Zakiy Firosy As Syahid, Zulfa Fauzia, Fakhri Naufal Marzuq, Runik Machfiroh, and Ihda Afifatunnuha Asumia

Adv. Sci. Lett. 23, 10774-10776 (2017)

[Abstract] [Full Text - PDF] [Purchase Article]

Automatic Statistical Inventory Reconciliation for Leak Detection of Petrochemical Storage

Nurul Hafizha Binti Musthafa, Yew Kwang Hooi, M. Fadzil Hassan, Azmi M. Shariff, and Khairul Shafee Khalid

Adv. Sci. Lett. 23, 10777-10781 (2017)

[Abstract] [Full Text - PDF] [Purchase Article]

Entrepreneurial Success and Resilience of Rural

Entrepreneurs in Kota Kinabalu, Sabah Under the Malaysian 1 Azam Programme

Riza Emifazura Jaafar, Airil Haimi Mohd Adnan, Zarul Azhar Nasir, Nor Marini Mohtar, and Abdul Malek A.Tambi

Adv. Sci. Lett. 23, 10782-10785 (2017)

[Abstract] [Full Text - PDF] [Purchase Article]

Modelling Effective Business Plan in Entrepreneurship

Education: A Solution Toward Better Learning

Siti Sara Ibrahim, Farrah Nadia Baharuddin, Nur Izzah Jamil, and Alia Nadia Rosle

Adv. Sci. Lett. 23, 10786-10789 (2017)

[Abstract] [Full Text - PDF] [Purchase Article]

Online Marketing Mix for Small Business

Dedy Chandra Haludin, Hasrini Sari, and Budhi Prihartono

Adv. Sci. Lett. 23, 10790-10793 (2017) 
Markov Switching Regression with Interval Data: Application to Financial Risk via CAPM

Pathairat Pastpipatkul, Paravee Maneejuk, and Songsak

Sriboonchitta

Adv. Sci. Lett. 23, 10794-10798 (2017)

[Abstract] [Full Text - PDF] [Purchase Article]

The Mediating Effect of Trust Toward Brand Social

Responsibility and Brand Loyalty Relationship

Mohd Raziff Jamaluddin, Salleh Mohd Radzi, and Hamizad Abdul

Hadi

Adv. Sci. Lett. 23, 10799-10802 (2017)

[Abstract] [Full Text - PDF] [Purchase Article]

Property Destruction, Human Losses and Economic Paralysis: Impact Flood in Kelantan

Zikri Muhamad, Bayu Taufiq Possumah, and Jaharudin Padli

Adv. Sci. Lett. 23, 10803-10805 (2017)

[Abstract] [Full Text - PDF] [Purchase Article]

Ablution Function Mean Analysis: A Prototype Design

Strategy for Sub-Sanitaryware Manufacturing

Rusmadiah Anwar, Verly Veto Vermol, Mohd Shaleh Mujir, and

Oskar Hasdinor Hassan

Adv. Sci. Lett. 23, 10806-10810 (2017)

[Abstract] [Full Text - PDF] [Purchase Article]

Directors' Remuneration and Corporate Financial Reporting Quality: A Conceptual Discussion

Nahariah Jaffar, Azleen Shabrina Mohd Nor, Zarehan Selamat, and Norhazlin Ismail

Adv. Sci. Lett. 23, 10811-10814 (2017)

[Abstract] [Full Text - PDF] [Purchase Article]

Designer Activity Experience: Blind User-Designer Activity

Model in Knowing Product Influence Through

Blind User Perspective

Verly Veto Vermol, Shahriman Zainal Abidin, Rusmadiah Anwar, and Oskar Hasdinor Hassan

Adv. Sci. Lett. 23, 10815-10821 (2017)

[Abstract] [Full Text - PDF] [Purchase Article]

Social Capital and Electronic Word-Of-Mouth (eWOM) Effect Toward Online Purchase Intention

Adhi Prasetio, Ratih Hurriyati, Puspita Kencana Sari, and Fetty

Poerwita Sary

Adv. Sci. Lett. 23, 10822-10825 (2017)

[Abstract] [Full Text - PDF] [Purchase Article]

Improving Efficiency of Administrative Processes-A Case

Study in a Service Sector

Josef Drahokoupil and Petra Maresova

Adv. Sci. Lett. 23, 10826-10829 (2017)

[Abstract] [Full Text - PDF] [Purchase Article]

Moderating Effects of Environmental Variables on the

Relationship Between BOS and Performance of Four and Five Star Hotels in Kuala Lumpur, Selangor, and Putrajaya, Malaysia

Salleh Mohd Radzi, Mohd Farih Mat Yasin, Mohd Salehuddin Mohd Zahari, Nur'Hidayah Che Ahmat, and

Mohd Hanafi Azman Ong

Adv. Sci. Lett. 23, 10830-10833 (2017)

[Abstract] [Full Text - PDF] [Purchase Article]

Teamwork and Collaboration in Healthcare: Elements of InterProfessional Teamwork

Sharifah Naziha Syed Kholed, Naffisah Mohd Hassan, Siti

Noorsuriani Ma'on, and Nur Zainie Abd Hamid

Adv. Sci. Lett. 23, 10834-10837 (2017)

[Abstract] [Full Text - PDF] [Purchase Article] 
Perspective Towards Allegations of

Anti-Hadith Groups

Rosni Wazir, Abur Hamdi Usman, Mohamad Jarpani Syopiyan, and Mohd Norzi Nasir

Adv. Sci. Lett. 23, 10838-10841 (2017)

[Abstract] [Full Text - PDF] [Purchase Article]

The Understanding of Bid'ah Concept from Hadith

Perspective

Mohd Fauzi Mohd Amin, Amran Abdul Halim, Abur Hamdi Usman, and Syed Najihuddin Syed Hassan

Adv. Sci. Lett. 23, 10842-10845 (2017)

[Abstract] [Full Text - PDF] [Purchase Article]

Innovation Open Chains: A Model of Competitiveness for Small and Medium-Sized Enterprises in Colombia

Angie M. Bermúdez, Cristian Riveros, and Maria Calderon Adv. Sci. Lett. 23, 10846-10849 (2017)

[Abstract] [Full Text - PDF] [Purchase Article]

Chartered Accountant as Career Preference in Malaysia: Role of Conscientiousness and Neuroticism

Nahariah Jaffar, Salmi Md Zahid, and Haslin Johari

Adv. Sci. Lett. 23, 10850-10854 (2017)

[Abstract] [Full Text - PDF] [Purchase Article]

Prophetic Based on Education: A Value Added for Social Change

Abur Hamdi Usman, Rosni Wazir, Muhammad Faiz Mukmin Abdul

Mutalib, and Khairul Munzir Ibrahim

Adv. Sci. Lett. 23, 10855-10858 (2017)

[Abstract] [Full Text - PDF] [Purchase Article]

Multicultural Influences on Malaysian Batik Sarong Design

Rafeah Legino

Adv. Sci. Lett. 23, 10859-10861 (2017)

[Abstract] [Full Text - PDF] [Purchase Article]

Malaysia's Chinese Opera Characters Visualized into Creative Visual Artwork

Nazzatul Izwanna Mohammad Sharan, Rafeah Legino, Ponirin Amin, and Juliana Manan

Adv. Sci. Lett. 23, 10862-10864 (2017)

[Abstract] [Full Text - PDF] [Purchase Article]

A Meta-Analysis Study on Teachers Qualification and Competencies in Indonesia

Agus Dudung

Adv. Sci. Lett. 23, 10865-10867 (2017)

[Abstract] [Full Text - PDF] [Purchase Article]

The Influence of Couple Interaction, Roles Differences, and Social-Economic Status on Mother's Stress Coping

Uswatun Hasanah, Nadiroh, and Amos Neolaka

Adv. Sci. Lett. 23, 10868-10870 (2017)

[Abstract] [Full Text - PDF] [Purchase Article]

Innovation Strategy of Small Industry Batik in Competitive Advantage

Aam Amaningsih Jumhur, Nik Hasnaa Nik Mahmood, and M. Muchdie

Adv. Sci. Lett. 23, 10871-10874 (2017)

[Abstract] [Full Text - PDF] [Purchase Article]

The Role of Social Influence, Team Exchange and Satisfaction in Explaining Intention to Volunteer at Green Events

Norol Hamiza Zamzuri, Siti Noorsuriani Maon, Wan Edura Wan

Rashid, Noor Azlina Mohamed Yunus,

Nurimanitasha Hussin, and Nor Lela Ahmad

Adv. Sci. Lett. 23, 10875-10877 (2017)

[Abstract] [Full Text - PDF] [Purchase Article]

The Effect of Values on the Perception of Sustainable Efforts

Towards Event Greening 
Nor Lela Ahmad, Nik Hasnaa Nik Mahmood, Wan Edura Wan Rashid, Noor Azlina Mohamed Yunus, Norol Hamiza Zamzuri, and Mohd Hanafi Azman Ong

Adv. Sci. Lett. 23, 10878-10882 (2017)

[Abstract] [Full Text - PDF] [Purchase Article]

The Concept of Using Reflexivity Theory to Examine the Perception of Sustainable Efforts Towards Event Greening Nor Lela Ahmad, Nik Hasnaa Nik Mahmood, Wan Edura Wan Rashid, and Noor Azlina Mohamed Yunus

Adv. Sci. Lett. 23, 10883-10886 (2017)

[Abstract] [Full Text - PDF] [Purchase Article]

Good Governance and Local Government in Contemporary Indonesian Context

Aminullah Assagaf, Abdul Hadi Sirat, and Taty Salmiaty

Adv. Sci. Lett. 23, 10887-10890 (2017)

[Abstract] [Full Text - PDF] [Purchase Article]

The Mediating Effect of Personal Norms Towards the

Relationship of Values and Perception of Event

Greening Efforts

Nor Lela Ahmad, Nik Hasnaa Nik Mahmood, Wan Edura Wan

Rashid, Noor Azlina Mohamed Yunus, and

Mohd Hanafi Azman Ong

Adv. Sci. Lett. 23, 10891-10894 (2017)

[Abstract] [Full Text - PDF] [Purchase Article]

Exploring the Dimension of Culture-Based Experience Quality

Dwi Suhartanto and Nono Wibisono

Adv. Sci. Lett. 23, 10895-10898 (2017)

[Abstract] [Full Text - PDF] [Purchase Article]

The Relationship Between Event Attendees' Behavior and Intentions to Attend Sustainable Events

Noor Azlina Mohamed Yunus, Norol Hamiza Zamzuri, Wan Edura

Wan Rashid, Nor Lela Ahmad, and

Sazimah Mohamed Salleh

Adv. Sci. Lett. 23, 10899-10902 (2017)

[Abstract] [Full Text - PDF] [Purchase Article]

Performance of Fiqh Teachers in the Learning Process at Madrasah Tsanawiyah (MTs) in Palopo-South Sulawesi Syamsu Sanusi

Adv. Sci. Lett. 23, 10903-10905 (2017)

[Abstract] [Full Text - PDF] [Purchase Article]

The Role of Marketing Strategy on Competitive Advantage and Its Impact on Home Sales in South Sulawesi

Mujahid and Yasir Haskas

Adv. Sci. Lett. 23, 10906-10909 (2017)

[Abstract] [Full Text - PDF] [Purchase Article]

Assessing Pre-Service Elementary School Teachers'

Alternative Conceptions Through a Four-Tier Diagnostic

Test on Magnetism Concepts

Neni Hermita, Andi Suhandi, Ernawulan Syaodih, Achmad

Samsudin, Isjoni, and Fitria Rosa

Adv. Sci. Lett. 23, 10910-10912 (2017)

[Abstract] [Full Text - PDF] [Purchase Article]

Learning Effectiveness of Short Course Productive Subject and Achievement Motivation Toward the Enhancement of Study Result in the Production Unit at Vocational High School in East Java

Marniati and Lutfiyah Hidayati

Adv. Sci. Lett. 23, 10913-10917 (2017)

[Abstract] [Full Text - PDF] [Purchase Article]

How to Implement Technology Science for Entrepreneurship by Using Product-Based Learning Approach and

Participatory Action Learning System in Higher Education?

Yuliana and Hendra Hidayat

Adv. Sci. Lett. 23, 10918-10921 (2017)

[Abstract] [Full Text - PDF] [Purchase Article] 
A Preliminary Development of Sundanese Local Wisdom Questionnaire (SLWQ) Through Educational College Students' Responses

R. Rokayah, D. Disman, and S. Sapriya

Adv. Sci. Lett. 23, 10922-10924 (2017)

[Abstract] [Full Text - PDF] [Purchase Article]

Customer Preferences in Selecting Commercial Bank in Malaysia

Nur Baiti Shafee, Shadia Suhaimi, Haniza Hashim, and Zuraina Salsabila Mohamed

Adv. Sci. Lett. 23, 10925-10928 (2017)

[Abstract] [Full Text - PDF] [Purchase Article]

Why Should History Teachers Develop Their Pedagogical Competences?

Isjoni Isjoni, Neni Hermita, and Achmad Samsudin

Adv. Sci. Lett. 23, 10929-10931 (2017)

[Abstract] [Full Text - PDF] [Purchase Article]

Developing Problem-Based Learning with Scaffolding Test (PBLST) in the Mathematical Context: An ADDIE-Model

Aryanti Aryanti, Didi Suryadi, and Turmudi Turmudi

Adv. Sci. Lett. 23, 10932-10934 (2017)

[Abstract] [Full Text - PDF] [Purchase Article]

The Effect of Transformational Leadership and Motivation on the Lecturer Performance in Environment of Navy

Command School (NCS)

Arya Delano

Adv. Sci. Lett. 23, 10935-10938 (2017)

[Abstract] [Full Text - PDF] [Purchase Article]

The Effect of Organizational Climate and Organizational Commitment on the Lecturer Performance in Navy Staff Command School (NSCS)

Frankie Oktolim Madethen

Adv. Sci. Lett. 23, 10939-10942 (2017)

[Abstract] [Full Text - PDF] [Purchase Article]

The Effect of Organizational Culture and Job Satisfaction to Principals Productivity in Senior High School in

Province of Jakarta

Dede Hamdani and Firmanul Catur Wibowo

Adv. Sci. Lett. 23, 10943-10946 (2017)

[Abstract] [Full Text - PDF] [Purchase Article]

Verbal Protocol Analysis Strategy for Product Design

Cognition: Preliminary Study on Metaphorical Form Element Norhidayah Md Zainuddin, Shahriman Zainal Abidin, Rusmadiah Anwar, and Oskar Hasdinor Hassan

Adv. Sci. Lett. 23, 10947-10951 (2017)

[Abstract] [Full Text - PDF] [Purchase Article]

The Use of Interactive-Compensatory Model Based-Learning Material to Improve Informational Text Reading

Comprehension Ability of 5th Grade Elementary School in

Bandung Regency Indonesia

Ryan Dwi Puspita, Dadang Sunendar, Bachrudin Musthafa, and

Rully Agung Yudiantara

Adv. Sci. Lett. 23, 10952-10954 (2017)

[Abstract] [Full Text - PDF] [Purchase Article]

Linkage Between McClelland Motivation Theory, Interpersonal Relationship, Employee Engagement and

Performance of Nurses at Adventist Hospital

Rolyana Ferinia and Stimson Hutagalung

Adv. Sci. Lett. 23, 10955-10958 (2017)

[Abstract] [Full Text - PDF] [Purchase Article]

Religiosity and Psychological Well-Being: Implication to Improve Disaster Management

Anissa Lestari Kadiyono and Diana Harding

Adv. Sci. Lett. 23, 10959-10962 (2017)

[Abstract] [Full Text - PDF] [Purchase Article] 
A SPECIAL SECTION

Selected Peer-Reviewed Articles from the 2016 International

Conference on Computational Science and

Engineering (ICCSE2016), Kota Kinabalu, Sabah, Malaysia,

29-30 November, 2016

Guest Editors: Rayner Alfred and Chin Kim On

Adv. Sci. Lett. 23, 10963-10964 (2017)

[Abstract] [Full Text - PDF] [Purchase Article]

\section{RESEARCH ARTICLES}

Responsive Web Design Trend in Malaysia Public Universities

Teh Shan Shan, Joe Henry Obit, Rayner Alfred, and Asni Tahir

Adv. Sci. Lett. 23, 10965-10968 (2017)

[Abstract] [Full Text - PDF] [Purchase Article]

Enhancing the Performance of University's Website for Mobile Devices Based on Responsive Web Design Approach

Teh Shan Shan, Joe Henry Obit, Rayner Alfred, and Asni Tahir

Adv. Sci. Lett. 23, 10969-10973 (2017)

[Abstract] [Full Text - PDF] [Purchase Article]

SME-ECD Design Framework of Motion-Based Game-Based

Learning and Assessment for Early

Childhood Education

Tin Tin Ting and Andrew Khin Huat Tan

Adv. Sci. Lett. 23, 10974-10977 (2017)

[Abstract] [Full Text - PDF] [Purchase Article]

Harvesting the Power of Serious Game for IT Education Mazeyanti M. Ariffin, Wan Fatimah Wan Ahmad, and Suziah Sulaiman

Adv. Sci. Lett. 23, 10978-10980 (2017)

[Abstract] [Full Text - PDF] [Purchase Article]

Imputation of Missing Rainfall Data Using Revised Normal

Ratio Method

Siti Nur Zahrah Amin Burhanuddin, Sayang Mohd Deni, and

Norazan Mohamed Ramli

Adv. Sci. Lett. 23, 10981-10985 (2017)

[Abstract] [Full Text - PDF] [Purchase Article]

A Novel Fast Reroute Signaling Cost for Multicast Proxy Mobility

Azana Hafizah Mohd Aman, Aisha-Hassan A. Hashim, Azween

Abdullah, and Huda Adibah Mohd Ramli

Adv. Sci. Lett. 23, 10986-10990 (2017)

[Abstract] [Full Text - PDF] [Purchase Article]

Evaluating Accessibility Criteria and Alternatives of Computer Applications for the Blind Using Analytical

Hierarchy Process

Manoranjitham Muniandy, Suziah Sulaiman, and K. S. Savita

Adv. Sci. Lett. 23, 10991-10995 (2017)

[Abstract] [Full Text - PDF] [Purchase Article]

Simulation of Power Measurement of Sequential Adiabatic

Circuit

Nurul Aisyah Nadiah Binti Zainal Abidin and Abu Khari Bin A'Ain

Adv. Sci. Lett. 23, 10996-11001 (2017)

[Abstract] [Full Text - PDF] [Purchase Article]

Improved Parameter Estimation for MRF Models for Varying Current

M. Khusyaie M. Razali, Asan G. A. Muthalif, N. H. Diyana Nordin, and Syamsul Bahrin

Adv. Sci. Lett. 23, 11002-11006 (2017)

[Abstract] [Full Text - PDF] [Purchase Article]

The Development of Conceptual KPI Model Based on

Balanced Scorecard Measurement Method for Tacit

Knowledge of Universities' Academic Staff

Zainab Amin, Awanis Romli, Rahmah Mokhtar, and Mazlina Abdul Majid

Adv. Sci. Lett. 23, 11007-11011 (2017)

[Abstract] [Full Text - PDF] [Purchase Article] 
A Performance Comparison of Metaheuristics Search for University Course Timetabling Problems

Joe Henry Obit, Kuan Yik Junn, and Rayner Alfred

Adv. Sci. Lett. 23, 11012-11015 (2017)

[Abstract] [Full Text - PDF] [Purchase Article]

A PSO Inspired Asynchronous Cooperative Distributed HyperHeuristic for Course Timetabling Problems

Joe Henry Obit, Rayner Alfred, and Mansour Hassani Abdalla

Adv. Sci. Lett. 23, 11016-11022 (2017)

[Abstract] [Full Text - PDF] [Purchase Article]

A Constraint Programming Approach to Solving University Course Timetabling Problem (UCTP)

Kuan Yik Junn, Joe Henry Obit, and Rayner Alfred

Adv. Sci. Lett. 23, 11023-11026 (2017)

[Abstract] [Full Text - PDF] [Purchase Article]

Performance Comparison of Linear and Non-Linear Great

Deluge Algorithms in Solving University Course

Timetabling Problems

Joe Henry Obit, Kuan Yik Junn, and Rayner Alfred

Adv. Sci. Lett. 23, 11027-11030 (2017)

[Abstract] [Full Text - PDF] [Purchase Article]

Compact Multislot Planar Monopole Antenna for Microwave Imaging

S. S. Tiang, Ibrahim Asyadh, Sardar Ali, and M. Z. Abdullah

Adv. Sci. Lett. 23, 11031-11034 (2017)

[Abstract] [Full Text - PDF] [Purchase Article]

Challenges in Predicting Wood Plastic Composites (WPCs)

Ritu Gupta, A. Noraziah, Arun Gupta, and Ainul Azila Che Fauzi

Adv. Sci. Lett. 23, 11035-11039 (2017)

[Abstract] [Full Text - PDF] [Purchase Article]

Stagnation-Point Flow Past a Permeable Stretching/Shrinking Sheet

Nor Ain Azeany Mohd Nasir, Anuar Ishak, and loan Pop

Adv. Sci. Lett. 23, 11040-11043 (2017)

[Abstract] [Full Text - PDF] [Purchase Article]

A Comparative Study of Neural Networks Methods and the African Buffalo Optimization for the Travelling

Salesman's Problems

Julius Beneoluchi Odili, Mohd Nizam Mohmad Kahar, and A.

Noraziah

Adv. Sci. Lett. 23, 11044-11047 (2017)

[Abstract] [Full Text - PDF] [Purchase Article]

Multi-View Video Plus Depth with Saliency Map Protection Norul Uyuun Mohd Noor, Hezerul Abdul Karim, Nor Azhar Mohd Arif, Mohd Haris Lye Abdullah, Aduwati Sali, and Mohammad Faizal Ahmad Fauzi

Adv. Sci. Lett. 23, 11048-11052 (2017)

[Abstract] [Full Text - PDF] [Purchase Article]

An Overview of Simultaneous Localization and Mapping Using Low-Cost Mini Robot Platform

Norhidayah Mohamad Yatim and Norlida Buniyamin

Adv. Sci. Lett. 23, 11053-11056 (2017)

[Abstract] [Full Text - PDF] [Purchase Article]

Dynamic Simulation Model of Cow's Milk Demand and Supply to Determine the National Fulfillment Ratio

Erma Suryani, Rully Agus Hendrawan, Isnaini Muhandhis, and Lily Puspa Dewi

Adv. Sci. Lett. 23, 11057-11061 (2017)

[Abstract] [Full Text - PDF] [Purchase Article]

A Conceptual Architecture of Sincerity in Software Agents for Task Performance

Nur Huda Jaafar, Mohd Sharifuddin Ahmad, and Azhana Ahmad

Adv. Sci. Lett. 23, 11062-11065 (2017)

[Abstract] [Full Text - PDF] [Purchase Article] 
Structural and Electronic Properties of 4-Bromo-2-(1HImidazo[4,5-b]Pyridin-2-yl)Phenol from Density Functional Theory Calculation

Pek-Lan Toh, Jee-Sien Char, Shukri Sulaiman, and MohamedIsmail Mohamed-Ibrahim

Adv. Sci. Lett. 23, 11066-11069 (2017)

[Abstract] [Full Text - PDF] [Purchase Article]

Resqku: An Emergency Mobile Application with Audible Sound Frequency

Oi-Mean Foong, Ai-Leng Cheong, and Kwang-Hooi Yew

Adv. Sci. Lett. 23, 11070-11073 (2017)

[Abstract] [Full Text - PDF] [Purchase Article]

An Architecture for Providing Context-Aware Security as a Service in Mobile Cloud Computing Environments

Muaamar Amer Alkubati, Syed Ahmad Aljunid, and Normaly Kamal Ismail

Adv. Sci. Lett. 23, 11074-11077 (2017)

[Abstract] [Full Text - PDF] [Purchase Article]

Behavioral Biometrics for User Authentication Using Self-

Refreshing SOM

Chee Siong Teh, Juen Ching Wong, and Ming Leong Yii

Adv. Sci. Lett. 23, 11078-11082 (2017)

[Abstract] [Full Text - PDF] [Purchase Article]

A Novel Triangulate Mapping Based on Self-Organized Anchor Points for Data Visualization

Ming Leong Yii and Chee Siong Teh

Adv. Sci. Lett. 23, 11083-11087 (2017)

[Abstract] [Full Text - PDF] [Purchase Article]

Managing Fragmented Database Using BVAGQ-AR

Replication Model

Ainul Azila Che Fauzi, A. Noraziah, T. Herawan, Z. Abdullah, and Ritu Gupta

Adv. Sci. Lett. 23, 11088-11091 (2017)

[Abstract] [Full Text - PDF] [Purchase Article]

Big Data Processing in Cloud Computing Environments

A. Noraziah, Mohammed Adam Ibrahim Fakherldin, Khalid Adam, and Mazlina Abdul Majid

Adv. Sci. Lett. 23, 11092-11095 (2017)

[Abstract] [Full Text - PDF] [Purchase Article]

High Speed Implementation of the Keyed-Hash Message Authentication Code (HMAC) Based on SHA-1 Algorithm Shamsiah Binti Suhaili and Takahiro Watanabe Adv. Sci. Lett. 23, 11096-11100 (2017)

[Abstract] [Full Text - PDF] [Purchase Article]

Review on Data Partitioning Strategies in Big Data Environment

A. A. Haneen, A. Noraziah, Ritu Gupta, and Mohammed Adam Ibrahim Fakherldin

Adv. Sci. Lett. 23, 11101-11104 (2017)

[Abstract] [Full Text - PDF] [Purchase Article]

Overview of Replication Techniques on Distributed Database in Cloud Environment

Sharifah Hafizah Sy Ahmad Ubaidillah and A. Noraziah

Adv. Sci. Lett. 23, 11105-11108 (2017)

[Abstract] [Full Text - PDF] [Purchase Article]

Overview Between Clustering and Load Balancing

A. Fairuzullah, A. Noraziah, and Ahmed N. Abdalla

Adv. Sci. Lett. 23, 11109-11113 (2017)

[Abstract] [Full Text - PDF] [Purchase Article]

An Agent Based Green Decision Making Model for Sustainable Information Technology Governance Bokolo Anthony Jr. and Mazlina Abdul Majid 
Adv. Sci. Lett. 23, 11114-11118 (2017)

[Abstract] [Full Text - PDF] [Purchase Article]

Brain Signal Analysis to Investigate Sound Effect on Memorization

Syarifah Noor Syakiylla Sayed Daud and Rubita Sudirman Adv. Sci. Lett. 23, 11119-11123 (2017)

[Abstract] [Full Text - PDF] [Purchase Article]

Securing IPv6 Link Local Communication Using IPSec:

Obstacles and Challenges

Amjed Sid Ahmed, Rosilah Hassan, and Nor Effendy Othman

Adv. Sci. Lett. 23, 11124-11128 (2017)

[Abstract] [Full Text - PDF] [Purchase Article]

Thermal Simulation of Light-Emitting Diode Panel with Heat

Sink

Koon Chun Lai, Chee Meng Loo, Kok Seng Ong, Kia Hock Tan,

Kim Ho Yeap, and Ming Hui Tan

Adv. Sci. Lett. 23, 11129-11133 (2017)

[Abstract] [Full Text - PDF] [Purchase Article]

Review on Green Technology Implementation Challenges in University Data Centre

Mohd. Rashid and A. Noraziah

Adv. Sci. Lett. 23, 11134-11137 (2017)

[Abstract] [Full Text - PDF] [Purchase Article]

A Big Data Prediction Framework for Weather Forecast Using MapReduce Algorithm

Khalid Adam, Mazlina Abdul Majid, Mohammed Adam Ibrahim

Fakherldin, and Jasni Mohamed Zain

Adv. Sci. Lett. 23, 11138-11143 (2017)

[Abstract] [Full Text - PDF] [Purchase Article]

Gesture Control as Assistive Technology

K. S. Savita, Anis Alia Mohamad Afifi, and Manoranjitham Muniandy

Adv. Sci. Lett. 23, 11144-11148 (2017)

[Abstract] [Full Text - PDF] [Purchase Article]

A Proposed Architecture for Generic and Scalable CDR Analytics Platform Utilizing Big Data Technology

Sara B. Elagib, Aisha-Hassan A. Hashim, and R. F. Olanrewaju

Adv. Sci. Lett. 23, 11149-11152 (2017)

[Abstract] [Full Text - PDF] [Purchase Article]

Boundary Layer Flow and Heat Transfer of a Nanofluid Over a Moving Permeable Surface

Siti Khuzaimah Soid, Anuar Ishak, and loan Pop

Adv. Sci. Lett. 23, 11153-11157 (2017)

[Abstract] [Full Text - PDF] [Purchase Article]

Economic and Emission Load Dispatch Solution via Artificial Bee Colony Algorithm

Mohd Noor Abdullah, Mohd Asyraf Ismail, Azralmukmin Azmi, Nur Hanis Mohammad Radzi, and Jasrul Jamani Jamian

Adv. Sci. Lett. 23, 11158-11161 (2017)

[Abstract] [Full Text - PDF] [Purchase Article]

An Integration of Unsupervised Approach of Machine Learning in Item Bank Test System

Anbuselvan Sangodiah and S. P. R. Charles Ramendran

Adv. Sci. Lett. 23, 11162-11165 (2017)

[Abstract] [Full Text - PDF] [Purchase Article]

Statistical Analysis of Ultra-Wideband Signed Decision Variable

G. C. Chung, S. S. Thwin, and M. Y. Alias

Adv. Sci. Lett. 23, 11166-11169 (2017)

[Abstract] [Full Text - PDF] [Purchase Article]

The Effect of Void in Thermal Layer on MOSFET's Heat

Dissipation 
M. S. Rosman, N. Buniyamin, M. H. Abdul Halim, and K. Lias Adv. Sci. Lett. 23, 11170-11173 (2017)

[Abstract] [Full Text - PDF] [Purchase Article]

Low-Cost Brainwave Controller

A. B. Abd Rahman, J. Samuel, A. Alias, and F. M. Yassin

Adv. Sci. Lett. 23, 11174-11177 (2017)

[Abstract] [Full Text - PDF] [Purchase Article]

Seamless Model Interoperability for Software Design and Analysis

Mohamed Ariff Ameedeen and Thong Weng Jie

Adv. Sci. Lett. 23, 11178-11181 (2017)

[Abstract] [Full Text - PDF] [Purchase Article]

Radiation Absorption Distribution of Hyperthermia

Rectangular Microstrip Applicator with Three Different

Substrates

Kasumawati Lias, Norlida Buniyamin, and Mohammad Zulkarnaen

Ahmad Narihan

Adv. Sci. Lett. 23, 11182-11186 (2017)

[Abstract] [Full Text - PDF] [Purchase Article]

Robustness Analysis of an Optimized Controller via Particle Swarm Algorithm

Chong Chee Soon, Rozaimi Ghazali, Hazriq Izzuan Jaafar, Syarifah Yuslinda Syed Hussein, and Sahazati Md. Rozali

Adv. Sci. Lett. 23, 11187-11191 (2017)

[Abstract] [Full Text - PDF] [Purchase Article]

Touch Sensation Based Computer Application to Facilitate the Learning Process of Dyslexic Children

M. Manoranjitham, Lim Kok Ooi, and K. S. Savita

Adv. Sci. Lett. 23, 11192-11196 (2017)

[Abstract] [Full Text - PDF] [Purchase Article]

An Expressive Hadoop MapReduce Framework

Nathar Shah and Christopher Messom

Adv. Sci. Lett. 23, 11197-11201 (2017)

[Abstract] [Full Text - PDF] [Purchase Article]

Consensus Phase of eDARA

SengKheau Chung, Rayner Alfred, HuiKeng Lau, Chin Kim On, Ag Asri Ag Ibrahim, Mohd Shamrie Sainin, and

Paulraj Murugesa Pandiyan

Adv. Sci. Lett. 23, 11202-11205 (2017)

[Abstract] [Full Text - PDF] [Purchase Article]

Early Childhood Educational Robotic System (C-Block): A

Design Methodology

Muralindran Mariappan, Jong Chia Sing, Manimehala Nadarajan, and Choo Chee Wee

Adv. Sci. Lett. 23, 11206-11210 (2017)

[Abstract] [Full Text - PDF] [Purchase Article]

Comparison of Clustering Algorithms Using Quality Metrics with Invariant Features Extracted from Plant Leaves

Jharna Majumdar and Shilpa Ankalaki

Adv. Sci. Lett. 23, 11211-11216 (2017)

[Abstract] [Full Text - PDF] [Purchase Article]

Optical Flow-Initiated Particle Filter Framework for Human-

Tracking and Body-Component Detection

Jharna Majumdar, Ashish Bhattarai, and Saurabh Adhikari

Adv. Sci. Lett. 23, 11217-11222 (2017)

[Abstract] [Full Text - PDF] [Purchase Article]

Design Methodology of Preserving Piano Playing Techniques Through Contactless Sensor System

Choo Chee Wee, Muralindran Mariappan, Razak Mohd Ali Lee,

Resot Iggau, Jong Chia Sing, and Wong Wei Kitt

Adv. Sci. Lett. 23, 11223-11227 (2017)

[Abstract] [Full Text - PDF] [Purchase Article] 
Application of Particle Swarm Optimization in Face Sketch Recognition

Hussein Samma and Shahrel Azmin Suandi

Adv. Sci. Lett. 23, 11228-11232 (2017)

[Abstract] [Full Text - PDF] [Purchase Article]

Comparison of Accuracy Performance Based on

Normalization Techniques for the Features Fusion of Face and Online Signature

Suryanti Awang, Junaida Sulaiman, Noorhuzaimi@Karimah Mohd Noor, and Luhur Bayuaji

Adv. Sci. Lett. 23, 11233-11236 (2017)

[Abstract] [Full Text - PDF] [Purchase Article]

Response Surface Modeling of Electrospinning Parameters on Titanium Oxide Nanofibers' Diameter:

A Box-Behnken Design (BBD)

Zi Sheng Tang, Nurmin Bolong, Ismail Saad, Ahmad Fauzi Ismail, and Franklin Tiam Yang Lim

Adv. Sci. Lett. 23, 11237-11241 (2017)

[Abstract] [Full Text - PDF] [Purchase Article]

Vertical Strained Impact Ionization MOSFET (VESIMOS)

Technology Approach for Based Biosensor

Applications Using Its Behavioral Model

Ismail Saad, B. Andee Hazwani Syazana, C. Bun Seng, H. Mohd.

Zuhir, and N. Bolong

Adv. Sci. Lett. 23, 11242-11246 (2017)

[Abstract] [Full Text - PDF] [Purchase Article]

Enhanced Reliability of Vertical Strained Impact Ionization MOSFET Incorporating Dielectric Pocket for

Ultra-Sensitive Biosensor Applications

Ismail Saad, H. Mohd. Zuhir, Andee H. S. Bacho, C. Bun Seng, A. M. Khairul, Bablu Ghosh, and N. Bolong

Adv. Sci. Lett. 23, 11247-11251 (2017)

[Abstract] [Full Text - PDF] [Purchase Article]

Performance Comparison and Electromagnetic Dosimetry of Rigid, Hybrid and Textile Antennas

Been Seok Yew, Fwen Hoon Wee, Saiful Bahri Mohamed, and Martini Muhamad

Adv. Sci. Lett. 23, 11252-11256 (2017)

[Abstract] [Full Text - PDF] [Purchase Article]

Enhancement of Under-Exposed Image for Object Tracking Algorithm Through Homomorphic Filtering and Mean Histogram Matching

Mohd Fauzi Abu Hassan, Ahmad Shahrizan Abdul Ghani,

Dhanesh Ramachandram, Abduljalil Radman, and

Shahrel Azmin Suandi

Adv. Sci. Lett. 23, 11257-11261 (2017)

[Abstract] [Full Text - PDF] [Purchase Article]

On the Throughput and Energy Consumption in External Sensing Cognitive Radio

Hemlata Patil, A. J. Patil, and S. G. Bhirud

Adv. Sci. Lett. 23, 11262-11266 (2017)

[Abstract] [Full Text - PDF] [Purchase Article]

Design and Analysis of an Efficient Repository System for Protein Coefficients in Systolic Array-Based Architecture by Using Xilinx Virtex-5 FPGA

M. N. Isa, D. Muhsen, M. I. Ahmad, S. A. Z. Murad, S. N. Mohyar, R. C. Ismail, and K. Benkrid

Adv. Sci. Lett. 23, 11267-11271 (2017)

[Abstract] [Full Text - PDF] [Purchase Article]

Securing E-Learning Environment: A Study of Security Awareness and Behavior of User

Wan Nurul Safawati Wan Manan, Mazlina Abdul Majid,

Hasmanizam Abdul Majid, and Mohd Izham Ibrahim

Adv. Sci. Lett. 23, 11272-11275 (2017)

[Abstract] [Full Text - PDF] [Purchase Article] 
Student Awareness on Social Network Access Control Policy

-An Evaluation of Facebook

Suzana Ahmad and Nurhayati Binti Zakaria

Adv. Sci. Lett. 23, 11276-11281 (2017)

[Abstract] [Full Text - PDF] [Purchase Article]

Policy Language: Enhancing JACIE for Data Ownership

Suzana Ahmad, Siti Zaleha Zainal Abidin, Nasiroh Omar, and Stephan Reiff-Marganiec

Adv. Sci. Lett. 23, 11282-11287 (2017)

[Abstract] [Full Text - PDF] [Purchase Article]

When Requirement Engineering Meets Computational Science Modelling and Simulation

WaiShiang Cheah, Shane Nissom, Jane Labadin, Nurfauza Jali, and HuiKeng Lau

Adv. Sci. Lett. 23, 11288-11292 (2017)

[Abstract] [Full Text - PDF] [Purchase Article]

Studies on Corrosion Inhibitor Activity of Azoles for Copper

L. Alamiparvin, E. Gorbani Kalhor, S. R. Nabavi, Sh. Ebrahimi, and

A. Farzamnia

Adv. Sci. Lett. 23, 11293-11297 (2017)

[Abstract] [Full Text - PDF] [Purchase Article]

On-Body Communication System Transmission Enhancement Using a Dual-Band Textile Artificial

Magnetic Conductor

M. A. Abdullah, M. K. A. Rahim, and N. A. Samsuri

Adv. Sci. Lett. 23, 11298-11301 (2017)

[Abstract] [Full Text - PDF] [Purchase Article]

Design of High Voltage and High Frequency Pulse Generator

Using DC Choke

Salamah Samsu, Fouziah Md Yassin, Fauziah Sulaiman, and Jedol Dayou

Adv. Sci. Lett. 23, 11302-11305 (2017)

[Abstract] [Full Text - PDF] [Purchase Article]

Review of Preventive Security Mechanisms for Neighbour Discovery Protocol

Mohammed Anbar, Rosni Abdullah, Redhwan M. A. Saad, and

Iznan H. Hasbullah

Adv. Sci. Lett. 23, 11306-11310 (2017)

[Abstract] [Full Text - PDF] [Purchase Article]

Study of Airflow Quality in the Intake Passage to Improve the Combustion Efficiency

A. B. Shahriman, A. Mohamad Syafiq, and M. S. M. Hashim

Adv. Sci. Lett. 23, 11311-11314 (2017)

[Abstract] [Full Text - PDF] [Purchase Article]

Correlation of Structural Modal Properties of Go-Kart Frame

Structure Using Different Type of Joint in Finite

Element Modeling

N. A. Z. Abdullah, M. S. M. Sani, and I. Zaman

Adv. Sci. Lett. 23, 11315-11319 (2017)

[Abstract] [Full Text - PDF] [Purchase Article]

Resolving Malay Word Sense Disambiguation Utilizing CrossLanguage Learning Sources Approach

Fuad Yahaya, Nurazzah Abd. Rahman, and Zainab Abu Bakar Adv. Sci. Lett. 23, 11320-11324 (2017)

[Abstract] [Full Text - PDF] [Purchase Article]

Investigation on Impact Hammer Testing with Different Types of Hammer Tip for Welded Thin Plate

S. N. Zahari and M. S. M. Sani

Adv. Sci. Lett. 23, 11325-11329 (2017)

[Abstract] [Full Text - PDF] [Purchase Article]

Contextual Thermal Face Detection for Fever Mass Screening Siti Sofiah, Kamarul Hawari, and Sabira Khatun Adv. Sci. Lett. 23, 11330-11334 (2017)

[Abstract] [Full Text - PDF] [Purchase Article] 
Study of Acceleration Plethysmogram Based Biometric Identification Incorporating Different Time Instances Siti Nurfarah Ain Mohd Azam and Khairul Azami Sidek Adv. Sci. Lett. 23, 11335-11339 (2017)

[Abstract] [Full Text - PDF] [Purchase Article]

Land Use and Land Cover Change in Vientiane Area, Lao PDR Using Object-Oriented Classification on Multi-Temporal Landsat Data

Su-Wah Hue, Alexius Korom, Yen-Wah Seng, Vongphet Sihapanya, Somvang Phimmavong, and Mui-How Phua Adv. Sci. Lett. 23, 11340-11344 (2017)

[Abstract] [Full Text - PDF] [Purchase Article]

Investment Decisions Based on EEG Emotion Recognition Nurul Izzati Mat Razi, Marini Othman, and Hamwira Yaacob Adv. Sci. Lett. 23, 11345-11349 (2017)

[Abstract] [Full Text - PDF] [Purchase Article]

Block Matching Algorithm (BMA) of the Hybrid Adaptive Rood Pattern Search (ARPS) Based on Its Motion Speed

Faizul Hadi Jamil, Ali Chekima, Farrah Wong Hock Tze, Rosalyn R. Porle, Razak Ali Lee, and Ismail Saad

Adv. Sci. Lett. 23, 11350-11354 (2017)

[Abstract] [Full Text - PDF] [Purchase Article]

Analysis of LTE-A Signal Strength in Indoor Mobility Environment

R. Mardeni, A. Alhammadi, F. Farhana Ruslan, K. Anuar, M. Y. Alias, and H. Mohamad

Adv. Sci. Lett. 23, 11355-11359 (2017)

[Abstract] [Full Text - PDF] [Purchase Article]

Deep CNN Object Features for Improved Action Recognition in Low Quality Videos

Saimunur Rahman, John See, and Chiung Ching Ho

Adv. Sci. Lett. 23, 11360-11364 (2017)

[Abstract] [Full Text - PDF] [Purchase Article]

The Assimilation of Multi-Type Information for Seasonal Precipitation Forecasting Using Modular Neural Network Junaida Sulaiman, Noorhuzaimi@Karimah Mohd Noor, and Suryanti Awang

Adv. Sci. Lett. 23, 11365-11368 (2017)

[Abstract] [Full Text - PDF] [Purchase Article]

Affective State Classification Through CMAC-Based Model of Affects (CCMA) Using SVM

Hamwira Yaacob and Abdul Wahab

Adv. Sci. Lett. 23, 11369-11373 (2017)

[Abstract] [Full Text - PDF] [Purchase Article]

A Hybrid Artificial Intelligence Algorithm to Determine the Speed and Position in Multi Operation Mode

Sensorless Brushed D.C. Motor

Brendan Khoo, Choo Chee Wee, Muralindran Mariappan, and Ismail Saad

Adv. Sci. Lett. 23, 11374-11377 (2017)

[Abstract] [Full Text - PDF] [Purchase Article]

$3 \mathrm{~dB}$ Branch-Line Coupler with Improved Bandwidth Using PDMS and Zoflex Conductor

S. A. Babale, S. K. A. Rahim, K. N. Paracha, and S. I. Orakwue Adv. Sci. Lett. 23, 11378-11381 (2017)

[Abstract] [Full Text - PDF] [Purchase Article]

An Impact of Controlling Energy Management System via Hybrid Battery-Supercapacitor in Electric Vehicles

N. A. N. Azahan, J. J. Jamian, Z. A. Noorden, and M. A. Baharudin Adv. Sci. Lett. 23, 11382-11386 (2017)

[Abstract] [Full Text - PDF] [Purchase Article]

Boyer-Moore Horspool Algorithm Used in Content 
Management System of Data Fast Searching

Chan Chung Hoong and Mohamed Ariff Ameedeen

Adv. Sci. Lett. 23, 11387-11390 (2017)

[Abstract] [Full Text - PDF] [Purchase Article]

The Effectiveness of Ergonomic Practice in Preventing Musculoskeletal Disorder Among Asian Construction Workers: Case Study in Kuala Lumpur, Malaysia

Ahmad Shakir Mohd Saudi, Razali Abdul Rahman, Muaz Mahmud,

Reezal Ishak, Ilyas Syafiq Darul Ridzuan,

Arvind Balakrishnan, Azman Azid, Hafizan Juahir, and Mohd

Haizam Mohd Saudi

Adv. Sci. Lett. 23, 11391-11394 (2017)

[Abstract] [Full Text - PDF] [Purchase Article]

A Systematic Literature Review of Case-Based Reasoning Based on Eco-Design Strategies for Environmental Product Design

Marziah Abdul Wahab, Awanis Romli, Al-Fahim Mubarak-Ali, and Mazlina Abdul Majid

Adv. Sci. Lett. 23, 11395-11399 (2017)

[Abstract] [Full Text - PDF] [Purchase Article]

A Fuzzy Proportional-Derivative (PD) Algorithm for

Programmable Logic Controller (PLC)

Renann G. Baldovino and Elmer P. Dadios

Adv. Sci. Lett. 23, 11400-11403 (2017)

[Abstract] [Full Text - PDF] [Purchase Article]

A Fuzzy-Based Pulse-Width Modulation (PWM) Control for Low Speed Autonomous Emergency Braking (AEB)

System: A Mini-Fuzzy Associative Matrix (FAM) Approach Renann G. Baldovino, Aira Patrice R. Ong, Paul Dominick E.

Baniqued, and Elmer P. Dadios

Adv. Sci. Lett. 23, 11404-11408 (2017)

[Abstract] [Full Text - PDF] [Purchase Article]

Shake Table System: A Review on the Different Mechanical Designs and Control Models

Renann G. Baldovino and Elmer P. Dadios

Adv. Sci. Lett. 23, 11409-11412 (2017)

[Abstract] [Full Text - PDF] [Purchase Article]

Comparison of Simulated Annealing and Great Deluge Algorithms for University Course Timetabling Problems (UCTP)

Kuan Yik Junn, Joe Henry Obit, and Rayner Alfred

Adv. Sci. Lett. 23, 11413-11417 (2017)

[Abstract] [Full Text - PDF] [Purchase Article]

An Improved Order-Statistical Filter for InSAR Phase Estimation

Lee Sui Ping, Chan Yee Kit, Lim Tien Sze, and Koo Voon Chet Adv. Sci. Lett. 23, 11418-11423 (2017)

[Abstract] [Full Text - PDF] [Purchase Article]

Adaptive Mobile Localization Method for Indoor Navigation Wahid Abdul, Haiyang Yu, Wenjun Yu, Sumi Kim, and Jaeho Choil Adv. Sci. Lett. 23, 11424-11427 (2017)

[Abstract] [Full Text - PDF] [Purchase Article]

An Overview of Crowd Evacuation Simulation

Noor Akma Abu Bakar, Mazlina Abdul Majid, and Khalid Adam Ismail

Adv. Sci. Lett. 23, 11428-11431 (2017)

[Abstract] [Full Text - PDF] [Purchase Article]

Vehicle Classification Using Passive Forward Scattering

Radar

Noor Hafizah Abdul Aziz and Muhammad Aizat Md Thani

Adv. Sci. Lett. 23, 11432-11436 (2017)

[Abstract] [Full Text - PDF] [Purchase Article]

Generalized QL-QR Decomposition Transceiver Design for Two-Way MIMO Relaying 
Analysis of Behavioral Intention of Mobile Application Usage Using Partial Least Squares

Geoffrey Harvey Tanakinjal, Stephen Laison Sondoh Jr., Rayner Alfred, and Ryan Macdonell Andrias

Adv. Sci. Lett. 23, 11440-11443 (2017)

[Abstract] [Full Text - PDF] [Purchase Article]

Graphical Representation of the Navigation Status in a WebBased Virtual Museum

Suziah Sulaiman, Dayang Rohaya Awang Rambli, Foong Oi

Mean, Nguyen Minh Tuan, and Fatin Shamimi M. Zuki

Adv. Sci. Lett. 23, 11444-11448 (2017)

[Abstract] [Full Text - PDF] [Purchase Article]

Multi-Finger Localization Feedback Using Vibrotactile Pattern Stimulation (VPS) for Prosthetic Hand

Yusof Bin Yunus, Yewguan Soo, Norhashimah Mohd Saad, Sani Irwan Md Salim, and Feng Duan

Adv. Sci. Lett. 23, 11449-11453 (2017)

[Abstract] [Full Text - PDF] [Purchase Article]

Consensus Process of Group Decision Making for Coastal Erosion Problem

Liana Najib, Ahmad Termimi Ab Ghani, Lazim Abdullah, and Mohammad Fadhli Ahmad

Adv. Sci. Lett. 23, 11454-11457 (2017)

[Abstract] [Full Text - PDF] [Purchase Article]

Retail Membership Model with Network Switch

A. G. Ateq Mezral and L. Muhamad Safiih

Adv. Sci. Lett. 23, 11458-11461 (2017)

[Abstract] [Full Text - PDF] [Purchase Article]

Low Voltage Wireless Power Transfer (WPT) Using Resonant Inductive Coupling Charging for

Short-Range Operation

Khairul Anuar Mohamad, Chia Ek Sel, Hoh Hang Tak, Afishah Alias, Ahmad Razani Haron, Farrah Wong.

Bablu Kumar Ghosh, and Ismail Saad

Adv. Sci. Lett. 23, 11462-11466 (2017)

[Abstract] [Full Text - PDF] [Purchase Article]

\section{A Finite Element Analysis of a Recurve Bow Riser Using} Carbon Fibre Hybrid Composites

F. A. Fauzi, Z. Ghazalli, J. P. Siregar, N. S. M. Noor, Z. Taha, Z. Ahmad, K. Kadirgama, N. H. Johari, and D. Mohamed

Adv. Sci. Lett. 23, 11467-11470 (2017)

[Abstract] [Full Text - PDF] [Purchase Article]

A Comparison of Muscular Activity Among European, Korea and Malaysian During Seating Using Musculoskeletal Computational Analysis Method

N. S. M. Noor, Z. Ghazalli, M. R. M. Rejab, F. A. Fauzi, R. Mamat, K. Kadirgama, M. S. M. Sani, Z. Ahmad, and N. H. Johari Adv. Sci. Lett. 23, 11471-11474 (2017)

[Abstract] [Full Text - PDF] [Purchase Article]

Three-Element Control System Manipulation in Steam Generation for Palm Oil Industry

I. M. Chew, F. Wong, A. Bono, and K. I. Wong

Adv. Sci. Lett. 23, 11475-11478 (2017)

[Abstract] [Full Text - PDF] [Purchase Article]

Impact of Mobility Speeds on LTE Network Performance Soon Fatt Boo, Wai Leong Pang, and Sew Kin Wong Adv. Sci. Lett. 23, 11479-11483 (2017)

[Abstract] [Full Text - PDF] [Purchase Article]

A Case Study of Agile Development Model in Malaysia Industry Practice 
Kheng Jin Leow, Xin Ni Lim, Pan Tong Lim, Tin Tin Ting, and Seah Fang Lee

Adv. Sci. Lett. 23, 11484-11488 (2017)

[Abstract] [Full Text - PDF] [Purchase Article]

Model Simplification for Electrical Impedance Tomography

Renee Ka Yin Chin, Gavin Thong Xian Kho, Heng Jin Tham, Bih Lii

Chua, Kenneth Tze Kin Teo, and Kwan Hoong Ng

Adv. Sci. Lett. 23, 11489-11493 (2017)

[Abstract] [Full Text - PDF] [Purchase Article]

Investigation of Electromagnetic Fields from LTE Base Station Soon Fatt Boo, Wai Leong Pang, Sew Kin Wong, Kah Yoong Chan, and Louai Alkhateb

Adv. Sci. Lett. 23, 11494-11497 (2017)

[Abstract] [Full Text - PDF] [Purchase Article]

Text Line Segmentation of Al-Quran Pages Using Binary Representation

Laith Bany Melhem, Mohd Sanusi Azmi, Azah Kamilah Muda,

Nazieh Jamil Bani-Melhim, and Mohammed Alweshah

Adv. Sci. Lett. 23, 11498-11502 (2017)

[Abstract] [Full Text - PDF] [Purchase Article]

Crawling Social Media to Create Morphological Resource of Under-Resourced Language: Melanau Language

Suhaila Saee, Ranaivo-Malancon Bali, Lay-Ki Soon, and Tek-Yong Lim

Adv. Sci. Lett. 23, 11503-11507 (2017)

[Abstract] [Full Text - PDF] [Purchase Article]

Multi-Mode Brainwave Controller

F. Md Yassin, D. Apin, A. B. Abd Rahman, and A. Alias

Adv. Sci. Lett. 23, 11508-11511 (2017)

[Abstract] [Full Text - PDF] [Purchase Article]

Segmenting Masses in Ultrasound Images by Using Seed

Based Region Growing and Mathematical Morphology

Aminah Abdul Malek, Wan Eny Zarina Wan Abdul Rahman, Mea

Haslina Mohd Haris, and Ummu Mardhiah Abdul Jalil

Adv. Sci. Lett. 23, 11512-11516 (2017)

[Abstract] [Full Text - PDF] [Purchase Article]

Feasibility Evaluation of Flexible Antenna Substrates for NearField Wireless Energy Transfer

Mohamad Harris Misran, Sharul Kamal Abdul Rahim, Akaa

Agbaeze Eteng, and Maizatul Alice Meor Said

Adv. Sci. Lett. 23, 11517-11520 (2017)

[Abstract] [Full Text - PDF] [Purchase Article]

\section{A Comparative Study of Pitch Detection Algorithms for} Microcontroller Based Voice Pitch Detector

Nuraina Suryani binti Ruslan, Mazlina Mamat, Rosalyn R. Porle, and Norfarariyanti Parimon

Adv. Sci. Lett. 23, 11521-11524 (2017)

[Abstract] [Full Text - PDF] [Purchase Article]

Magnetoelectric Effects Analysis of a Hybrid Piezoelectric Cantilever

Md Rabiul Awal, Muzammil Jusoh, Thennarasan Sabapathy,

Muhammad Ramlee Kamarudin, and H. A. Rahim

Adv. Sci. Lett. 23, 11525-11529 (2017)

[Abstract] [Full Text - PDF] [Purchase Article]

Implementation of Energy Efficient Thermal Comfort Control for Cyber-Physical Home Systems

Lim Yuto, Ooi Sian En, Makino Yoshiki, Teo Tze Kin, Rayner

Alfred, and Tan Yasuo

Adv. Sci. Lett. 23, 11530-11534 (2017)

[Abstract] [Full Text - PDF] [Purchase Article]

Self Charging Solar Battery for Ground Forward Scatter Radar (FSR) Micro Sensor

Kama Azura Othman and Muhammad Hafizul Ariff Mohd Bardiri

Adv. Sci. Lett. 23, 11535-11539 (2017) 
Impact of Window's Height on Energy Efficiency in AirConditioned Office Buildings

Najib Taher Al-Ashwal and Ahmad Sanusi Hassan

Adv. Sci. Lett. 23, 11540-11544 (2017)

[Abstract] [Full Text - PDF] [Purchase Article]

Capacitated Maximal Covering Location Allocation Problem During Flood Disaster

Noridayu Mah Hashim, S. Sarifah Radiah Shariff, and Sayang Mohd Deni

Adv. Sci. Lett. 23, 11545-11548 (2017)

[Abstract] [Full Text - PDF] [Purchase Article]

Effect of the Length on the Tensile Deformation of Nickel Nanowires Using Molecular Dynamics Simulations

A. G. N. Sofiah, M. Samykano, J. Rivas Murillo, N. A. C. Lah, D.

Ramasamy, K. Kadirgama, and M. M. Rahman

Adv. Sci. Lett. 23, 11549-11552 (2017)

[Abstract] [Full Text - PDF] [Purchase Article]

Dynamic Reconfiguration of Web Service in Service-Oriented Architecture

Rahmat Ilahi, Novia Admodisastro, Norhayati Mohd Ali, and Abu

Bakar Md. Sultan

Adv. Sci. Lett. 23, 11553-11557 (2017)

[Abstract] [Full Text - PDF] [Purchase Article]

Heterogeneous Broadband Communication Network Based on TV White Spectrum

Zhenjia Chen and Yonghui Zhang

Adv. Sci. Lett. 23, 11558-11563 (2017)

[Abstract] [Full Text - PDF] [Purchase Article]

Annealing Dependence on Structural and Electrical

Characteristic of $n-\mathrm{ZnO} / p-\mathrm{CuGaO}_{2}$ Transparent

Heterojunction Diode

Muhammad Hafiz Abu Bakar, Lam Mui Li, Khairul Anuar

Mohamad, Fouziah Md. Yassin, Chee Fuei Pien,

Afishah Alias, and Katsuhiro Uesugi

Adv. Sci. Lett. 23, 11564-11566 (2017)

[Abstract] [Full Text - PDF] [Purchase Article]

\section{Class Diagram Critic: A Design Critic Tool for UML Class} Diagram

Soran Mahmood Abdulkareem, Norhayati Mohd Ali, Novia

Admodisastro, and Abu Bakar Md Sultan

Adv. Sci. Lett. 23, 11567-11571 (2017)

[Abstract] [Full Text - PDF] [Purchase Article]

\section{A Denoising Algorithm for InSAR Surface Deformation} Application

Lee Sui Ping, Chan Yee Kit, and Lim Tien Sze

Adv. Sci. Lett. 23, 11572-11577 (2017)

[Abstract] [Full Text - PDF] [Purchase Article]

Measuring Usability of Phonic Mobile Applications Based on User Success Rate for Pre-School Children

Carolyne Alphonsus Tommy and Jacey-Lynn Minoi

Adv. Sci. Lett. 23, 11578-11581 (2017)

[Abstract] [Full Text - PDF] [Purchase Article]

Programmable MBIST with High Flexibility Control

Nor Azura Zakaria and Lee Weng Fook

Adv. Sci. Lett. 23, 11582-11587 (2017)

[Abstract] [Full Text - PDF] [Purchase Article]

Comparative Study on the Sunlight Penetration Extent on High-Rise Apartment Facades with Early Modern

Architectural Style Design in Kuala Lumpur, Malaysia

Yasser Arab, Ahmad Sanusi Hassan, and Bushra Qanaa

Adv. Sci. Lett. 23, 11588-11592 (2017)

[Abstract] [Full Text - PDF] [Purchase Article] 
Improved Boosting Algorithms by Pre-Pruning and Associative Rule Mining on Decision Trees for Predicting Obstructive Sleep Apnea

Doreen Ying Ying Sim, Chee Siong Teh, and Ahmad Izuanuddin Ismail

Adv. Sci. Lett. 23, 11593-11598 (2017)

[Abstract] [Full Text - PDF] [Purchase Article]

Inconsistency Detection of Model and Code via Critic-Based Approach

Osman Mohammed, Norhayati Mohd Ali, Novia Admodisastro, and Jamilah Din

Adv. Sci. Lett. 23, 11599-11603 (2017)

[Abstract] [Full Text - PDF] [Purchase Article]

A Single-Phase Multilevel Inverter for Stand-Alone Hybrid PV/Battery Residential Application

Mohammad Farhadi Kangarlu, Sadjad Galvani, and Ali Farzamnia

Adv. Sci. Lett. 23, 11604-11608 (2017)

[Abstract] [Full Text - PDF] [Purchase Article]

Banking Automation with Sustainable Hedging for Information Risks: BASHIR Framework for Private Clouds

Shahid Anjum

Adv. Sci. Lett. 23, 11609-11612 (2017)

[Abstract] [Full Text - PDF] [Purchase Article]

On the Minimum Slicing Problem

Liawas Barukang and Rayner Alfred

Adv. Sci. Lett. 23, 11613-11615 (2017)

[Abstract] [Full Text - PDF] [Purchase Article]

Adaptiation Gear and Pinion Formulation to Produce Epicycloid Graphic Simulation for Food Printing

M. K. Wan Ibrahim, Azali Saudi, and Mohd Adnan Mohd Salleh

Adv. Sci. Lett. 23, 11616-11619 (2017)

[Abstract] [Full Text - PDF] [Purchase Article]

Image Processing-Based Handwriting Recognition for Automated Form Processing

Ellysha Astin Anak Sirai, Farrah Wong, Ali Chekima, and Lim Pei Yi Adv. Sci. Lett. 23, 11620-11624 (2017)

[Abstract] [Full Text - PDF] [Purchase Article]

Analyzing the Effect of Top Management Support on Accounting Information System (AIS) Success

Yenni Carolina and Azhar Susanto

Adv. Sci. Lett. 23, 11625-11628 (2017)

[Abstract] [Full Text - PDF] [Purchase Article]

An Empirical Investigation of the Accounting Information System Quality

Rapina Rapina and Azhar Susanto

Adv. Sci. Lett. 23, 11629-11633 (2017)

[Abstract] [Full Text - PDF] [Purchase Article] 


\title{
Performance of Fiqh Teachers in the Learning Process at Madrasah Tsanawiyah (MTs) in Palopo-South Sulawesi
}

\author{
Syamsu Sanusi \\ Department of Tarbiyah and Education Science, Institut Agama Islam Negeri, Palopo-South Sulawesi
}

\begin{abstract}
The purpose of this paper is aiming to reveal the performance of fiqh teachers in the learning process at MTs in the District of Palopo, South Sulawesi. This research uses quantitative method with descriptive approach of pedagogic and management. Data collection methods such as questionnaire, interview, observation, and documentation employed among 26 respondents encompass teachers, supervisors, headmasters, and students of MTs in Palopo and applied univariate descriptive statistics to analyzed the collected data. Regulation of the Minister for the Control of State Apparatus and Bureaucracy Reform No. 16 of 2009 Article 15 is used as a reference for assessing teacher performance in learning process. The results show that the performance of fiqh teachers has an average value score of 75.59 which means that if this score converted to the scale 1-100 then it is spotted in the interval score of $61-75$. This implies that the performance quality of figh teachers in learning process at MTs in Palopo, categorized as enough.
\end{abstract}

Keywords: Performance, Fiqh Teacher, Learning Process.

\section{INTRODUCTION}

Performance is the appearance of one's work in the form of quality or quantity in an organization. 5 , p. 150 This premise requires management performance. According to Jones, management performance is a strategic and integrated process that deliver sustainable to organizations by improving the performance of people who work in and by developing the capabilities of individual and team contributions. 7 , p. 75

Performance in the context of education quality in an educational institution is determined by its teacher's performance and professionalism. Contrary, teacher performances below set of standards indicates failure to respect their profession. Discipline as one of the internal factors needs to be considered in an effort to improve the performance of teacher. Barnawi ${ }^{3, p .} 109$ states that neglected discipline in teaching process would be a poor work culture that degrade the performance of teacher. Education quality at school is largely determined by the performance of teachers in learning process. Effectiveness of learning can be achieved when teachers work earnestly. The mighty Allah commands His servants to work earnestly. Allah and His Messenger and the believers will see His servants' work and assess them (Q. S. Al-Tawbah/9: 105).

Fiqh subject in MTs plays an important role in imparting the basics of worship to the students. Standard contents of fiqh subject among others are such as purification, ablutions, prayer, sacrifice, charity, and selling. These contents are sufficient as a basis for students to understand and practice of worship. Therefore, fiqh teachers morally carry out their profession obligation in educating, guiding and directing the students to practice their religion and muamalah in accordance with Islamic law.

In fact, the understanding of MTs students in Palopo in term of the laws in worship and ability to apply is least. For instance, the phenomenon of learning outcomes of fiqh found that there were still baliq students claim that only once or two times a day to do the pray, even more some students stated that they did not consistent to pray regularly. Another example revealed in term of taharah that they do not know how to deal when menstruation comes for woman and a wet dream for man. Actually, fiqh teachers at MTs in Palopo partially are certified as professional educators especially at public madrasah. Yet, new temporary teachers relatively are not certified in teaching profession. Therefore, some issues in fiqh teachers' competence in several Islamic schools in Palopo need more attention from policy makers in order to minimize discrepancies learning process and the outcomes.

This study conducted to reveal aspects of performance in learning process and assessment indicators on MTs in Palopo to improve the performance quality encompasses study 
plans, implementation of learning, and assessment of learning outcomes.

\section{TEACHER PERFORMANCE IN THE LEARNING PROCESS}

\subsection{Aspect of Study Plan}

The performance of teachers in aspect of study plan appear in their annual program, semester program, syllabus and learning implementation plan as well as teaching and material sources. Essential indicators of this aspect are:

a. Teacher formulates learning objectives in accordance with the syllabus and notices the characteristics of students.

b. Teacher prepares teaching materials sequentially, logical, and contextual.

c. Teacher plans an effective learning activity.

d. Teacher selects the sources and learning media in accordance with the material and learning strategies.

The result of analysis from respondents related to indicators of study plan aspects are presented in the following Table I.

The data above shows the performance of fiqh teachers on study plan aspects obtained an average score of 76.55. If this score converted to a scale of 1-100, it is in the interval of 76-90. It means that the quality of fiqh teacher performance on study plan aspect in Palopo categorized as good.

\subsection{Learning Implementation Aspect}

Teacher performance on the learning implementation aspect is associated to the competency accordance to the implementation of learning. Essential indicators in this aspect are:

a. Teacher begins learning effectively.

b. Teacher masteries the subject matter.

c. Teacher carries-out particular approaches and strategies for effective learning.

d. Teacher utilizes the resources and media in learning.

e. Teacher triggers and maintains the involvement of students in learning.

f. Teacher uses correct and appropriate language in learning process.

The results of analysis from respondents related to the learning implementation aspect are presented in the following Table II.

The result shows the performance of fiqh teachers on learning implementation aspect obtained an average score of 72.51. If this score converted to a scale of 1-100, it is in the interval of 61-75. It means that the quality of fiqh teacher performance on learning implementation aspect in Palopo categorized as enough.

Table I. Performance of fiqh teachers on lesson planning aspect.

\begin{tabular}{llccc}
\hline & & \multicolumn{2}{c}{ Study plan } & Score \\
\cline { 3 - 4 } No. & \multicolumn{1}{c}{ Institution } & Supervisors & Headmasters & $\begin{array}{c}\text { Herage } \\
\text { averan }\end{array}$ \\
\hline 1 & MTs Negeri (A) & 93.8 & 88.6 & 91.2 \\
& MTs Negeri (B) & 93.8 & 95.3 & 94.6 \\
2 & MTs DatokSulaiman & 71.9 & 85.9 & 78.9 \\
3 & MTs DDI 1 Palopo & 80.4 & 74.2 & 77.3 \\
4 & MTs Madani Jaya & 68.8 & 68.8 & 68.8 \\
5 & MTs DDI 3 Purangi & 60 & 56.3 & 56.3 \\
6 & MTs HalimahTussa'diyah & 68.8 & 68.8 & 68.8 \\
& Total & & & 535.9 \\
& Average & & & 76.55 \\
\hline
\end{tabular}

Table II. Performance of fiqh teachers on learning implementation aspect.

\begin{tabular}{llcccc}
\hline & & \multicolumn{3}{c}{ Learning implementation } & Score \\
\cline { 3 - 4 } No. & \multicolumn{1}{c}{ Institution } & Supervisors & Headmasters & Students & Serage \\
\hline 1 & MTs Negeri (A) & 92.9 & 90.2 & 72.6 & 85.2 \\
& MTs Negeri (B) & 87.5 & 93.8 & 76.8 & 86 \\
2 & MTs DatokSulaiman & 71.4 & 81.3 & 69.9 & 74.2 \\
3 & MTs DDI 1 Palopo & 75 & 58.1 & 62.5 & 65.2 \\
4 & MTs Madani Jaya & 75 & 58.9 & 50.4 & 61.4 \\
5 & MTs DDI 3 Purangi & 60.2 & 63.8 & 51 & 58.3 \\
6 & MTs Halimatussa'diyah & 87.7 & 82.1 & 63.1 & 77.6 \\
& Total & & & & 507 \\
& Average & & & & 72.51 \\
\hline
\end{tabular}

\subsection{Learning Outcomes Assessment Aspect}

Performance of fiqh teacher on learning outcomes assessment aspect is directed to the competencies of teachers in measuring progress and success of students. Essential indicators in this aspect are:

a. Teacher designs assessment tool to measure progress and success of student.

b. Teacher uses a variety of strategies and assessment methods to monitor the progress and results of students in achieving certain competence as written in the study plan.

c. Teacher takes advantage of a variety of assessments to provide feedback to students about their learning progress and drafting materials for further learning.

The results of data analysis from respondents about fiqh teachers performance indicators on learning outcomes assessment aspect are presented in the following Table III.

The result above attained an average score of 77.68. If this score converted to a scale of 1-100, it is in the interval of 76-90. It means that the quality of fiqh teacher performance on learning outcomes assessment aspect categorized as good.

To sum up all the scores of fiqh teacher performance based on three aspects of learning process as presented above, the following Table IV combines all of them.

The accumulation value result as shown above is obtained an average score of 75.59. If this score is converted to a scale of $1-100$, it is in the interval of $61-75$. It can be concluded that the quality of fiqh teacher performance in learning process at MTs in Palopo categorized as enough

Based on the above analysis, the result indicates that the performance of fiqh teachers in the learning process at MTs in Palopo-South Sulawesi has not been optimal. The result

Table III. Fiqh teachers performance on aspect of learning outcomes assessment.

\begin{tabular}{llccc}
\hline & & \multicolumn{2}{c}{ Learning outcomes assessment } & \multirow{2}{*}{$\begin{array}{c}\text { Score } \\
\text { Noverage }\end{array}$} \\
\cline { 3 - 4 } No. & \multicolumn{1}{c}{ Institution } & Supervisors & Headmasters & 97.5 \\
\hline 1 & MTs Negeri (A) & 95 & 100 & 95 \\
& MTs Negeri (B) & 95 & 95 & 81.25 \\
2 & MTs DatokSulaiman & 80 & 82.5 & 75 \\
3 & MTs DDI 1 Palopo & 75 & 75 & 70 \\
4 & MTs Madani Jaya & 70 & 70 & 61.25 \\
5 & MTs DDI 3 Purangi & 65 & 57.5 & 63.75 \\
6 & MTs Halimatussa'diyah & 65 & 62.5 & 543.75 \\
& Total & & & 77.68 \\
\hline
\end{tabular}


Table IV. Accumulated average score of fiqh teachers performance in learning process.

\begin{tabular}{|c|c|c|c|c|c|}
\hline \multirow[b]{2}{*}{ No. } & \multirow[b]{2}{*}{ Institution } & \multicolumn{3}{|c|}{$\begin{array}{l}\text { Average score of fiqh teachers } \\
\text { performance based on aspects }\end{array}$} & \multirow{2}{*}{$\begin{array}{c}\text { Score } \\
\text { average }\end{array}$} \\
\hline & & Planning & Implementation & Assessment & \\
\hline \multirow[t]{2}{*}{1} & MTs Negeri $(A)$ & 91.2 & 85.2 & 97.5 & 91.3 \\
\hline & MTs Negeri (B) & 94.6 & 86 & 95 & 91.86 \\
\hline 2 & MTs DatokSulaiman & 78.9 & 74.2 & 81.25 & 78.11 \\
\hline 3 & MTs DDI 1 Palopo & 77.3 & 65.2 & 75 & 72.5 \\
\hline 4 & MTs Madani Jaya & 68.8 & 61.4 & 70 & 66.73 \\
\hline 5 & MTs DDI 3 Purangi & 56.3 & 58.3 & 61.25 & 58.61 \\
\hline \multirow[t]{3}{*}{6} & MTs Halimatussa'diyah & 68.8 & 77.6 & 63.75 & 70.05 \\
\hline & Total & 535.9 & 507.9 & 543.75 & 529.16 \\
\hline & Average & 76.55 & 72.55 & 77.68 & 75.59 \\
\hline
\end{tabular}

consistent with the statement of Danim, ${ }^{4, \text { p. }} 19$ that training, teaching professionally and career development are associated to increase the competence and performance of teacher in the implementation of education and learning process. Efforts to improve teacher's performance should be in line with the award, enhance prosperity, and protection. Agustian ${ }^{1, p .} 146$ emphasizes at aspects of leadership such honest nature, inspirational, thoughtful, intelligent, competent, courageous, fair, working, patient, and visionary significantly impact on teacher's performance.

Another conducted study by Humaini (2010: 525) reveals that the implementation of teacher certification has shown a positive impact on the performance of teachers in learning process. The study concluded that the better implementation of certification benefits the better the performance of teachers. In line with Aritonang 2, pp. 13,14 expresses his research on compensation, work discipline, and teachers' performance at SMP Kristen BPK Penabur Jakarta says there was a positive relationship between compensation with performance of teachers, also between teacher working discipline and teacher's performance.

The results of this study prove the existence of expectancy theory propounded by Vroom (1964), that motivating someone to work hard in doing his job depends on a reciprocal relationship between what people want and need from output of that work. ${ }^{a}$

Expectancy is one of the driving forces which lie behind someone to perform an action. In this theory, a person will maximize something benefit and minimize something detrimental to the achievement of the goal. Expectancy theory explains that in order to produce a high performance, one must have a high motivation and ability. On the other hand, if a person has low motivation and ability then the performance will resulted as low. The substance of expectancy theory has in line with the Mangkunagara's opinion (2001: 67), that the level of worker performance is closely related to reward systems applied by the institution where they occupied. Reward can affect the improvement of one's performance.

Teacher who has a superior ability, professional, and highly motivated in carrying out the task of learning leads to produce good quality graduates. Teacher who has motivation to achieve good performance will attain optimum performance. Contrary, teacher who has lack motivation tends to result in lower performance eventually. Therefore, working condition and situation experienced by each individual teacher, contributes to the achievement of performance.

Based on the findings of this study, it is recommended that researchers interested in conducting research on the performance of teachers to focus on efforts made by the government of Palopo region for the development and professionalism of teachers of figh in particular and general religious teachers so as to contribute in realizing the national education goals that is development of potential participants to be a human being who is faithful and devoted to God Almighty, having good character, healthy, knowledge, creative, independent, being a democratic citizen, and responsible (Act No. 20 Year 2003, 2011: 7).

\section{CONCLUSION}

Based on the description above, the performance of fiqh teachers in the learning process at MTs in Palopo South Sulawesi has not been optimal. The analysis indicators of teacher performance refers to the Ministry of Administrative and Bureaucracy Reform No. 16 of 2009 Article 15, obtained an average score 75.59. If this score is converted to a scale of $1-100$, it is in the interval of 61-75. It means that the quality of fiqh teacher performance in the learning process at MTs in Palopo is categorized as enough. The finding of this study is needed for continuous development of professional teacher and to formulate a reward funds scheme equally to encourage in improving the quality of teacher performance.

\section{References and Notes}

1. G. A. Agustian, Rahasia Sukses Membangun Kecerdasan Emosi dan Spiritual ESQ. Cet. V; Arga Publishing, Jakarta (2001).

2. K. T. Aritonang, Kompensasi Kerja, Disiplin Kerja Guru dan Kinerja Guru SMP, Jurnal Pendidikan Penabur, No. 04/Th.IV/Juli 2005 (2005)

3. Barnawi dan Mohammad Arifin, Kinerja Guru Profesional, Cet. I, Ar-Ruzz Media, Yogyakarta (2012).

4. S. Danim, Profesionalisasi dan Etika Profesi Guru, Cet. I; Alfabeta, Bandung (2010)

5. Muhammad dan Hindama Ruhyanani Fathurrohman, Sukses Menjadi Pengawas Sekolah Ideal, Cet. I; Ar-Ruzz Media, Yogyakarta (2015).

6. M. Hurmaini, Dampak Pelaksanaan Sertifikasi Guru terhadap Peningkatan Kinerja Guru dalam Proses Pembelajaran: Studi pada Madrasah Tsanawiyah Negeri Kota Jambi (2010), Vol. 26.

7. J. Jones, M. Jenkin, and S. Lord, Developing Effective Teacher Performance, London, Paul Chapman Publishing (2006).

8. Mangkunegara and A. A. Anwar Prabu, Manajemen Sumber Daya Manusia Perusahaan, Remaja Rosdakarya, Bandung (2001)

9. Peraturan Menteri Negara Penertiban Aparatur Negara dan Reformasi Birokrasi Nomor 16 Tahun 2009 tentang, Jabatan Fungsional Guru dan Angka Kreditnya.

10. T. D. D. Rahmawati, Penilaian Kinerja Profesi Guru dan Angka Kreditnya, Yogyakarta, Gaya Media (2013)

11. D. M. Ronnie, The Power of Emotional and Adversity Quotient for Teachers, Cet.l; Mizan Publik, Bandung (2006)

12. J. H. Stronge and P. D. Tucker, Handbook on teacher evaluation: Assessing and improving performance, Eye on Education, Larchmont, New York (2006).

13. J. H. Stronge, R. G. Christopher, and C. A. Little, Teacher Pay and Teacher Quality: Attracting, Developing, and Retaining, the Best Teachers, Corwin Press, California (2006).

14. J. R. Wilkerson and W. S. Lan, Assessing Teacher Competency, Corwin Press, California (2007).

15. http://www.yourcoach.be/en/employee-motivation-theories/vroomexpectancy-motivation-theory.php, diakses 15 Nopember 2016. 